\title{
RELIABILITY OF MEASURING VARIOUS CONTRACTILE FUNCTIONS OF FINGER FLEXORS OF MEN OF VARIOUS AGES
}

\author{
Milan R. Marković ${ }^{1}$, Milivoj Dopsaj ${ }^{1}$, Nenad Koropanovski ${ }^{2}$, Nemanja Ćopić ${ }^{3}$, Marija Trajkov ${ }^{4}$ \\ ${ }^{1}$ University of Belgrade, Faculty of Sport and Physical Education, Belgrade, Serbia \\ ${ }^{2}$ The Academy of Criminalistic and Police Studies, Belgrade, Serbia \\ ${ }^{3}$ University Union “Nikola Tesla”, Faculty of Sport, Belgrade, Serbia \\ ${ }^{4}$ College of Sport and Health, Belgrade, Serbia
}

\begin{abstract}
The aim of the research is to determine the reliability of testing various contractile functions of a male hand based on motoric and functional dominance and age. The examinee takes a seat with their arm extended or mildly flexed in a mildly abducted position. For the measuring purposes, dynamometric probe with isometric straining conditions fixed to a special construction was used. The "Isometrics" (ver. 3.1.1) was used and frequency of data selection was realized on the level of $500 \mathrm{~Hz}$. The sample includes 269 male examinees aged from 14.0 to 69.9. The results of descriptive statistics have shown that in relation to the tested sample for the non-dominant hand, values for maximum force $\left(\mathrm{F}_{\mathrm{max}}\right)$ range from 462.8 to $529.0 \mathrm{~N}$, for explosive force $\left(\mathrm{RFD}_{\max }\right.$ ) the range is from 1621.6 to $1972.8 \mathrm{~N} / \mathrm{s}$ and for muscular force impulse $\left(\mathrm{I}_{\mathrm{mp}} \mathrm{F}_{50 \% \max }\right)$ from 8203.9 to $15552.3 \mathrm{Ns}$, while $\mathrm{F}_{\max }$ values the dominant hand ranges from 478.1 to $566.2 \mathrm{~N}$, for RFDmax it ranges from 1742.6 to $2119.0 \mathrm{~N} / \mathrm{s}$ and for $\mathrm{I}_{\mathrm{mp}} \mathrm{F}_{50 \% \max } 9516.7$ to $16845.1 \mathrm{Ns}$. The results have shown that it is reliable to measure all three examined contractile hand characteristics where by ICC ranges from 0.938 to 0.977 for $\mathrm{F}_{\max }$, from 0.903 to 0.971 for RFD $\max _{\text {ax }}$ and from 0.747 to 0.943 for $\mathrm{I}_{\operatorname{mp}} \mathrm{F}_{50 \% \max }$. The second try as the better result should be considered the representational value for $\mathrm{F}_{\max }$ and $\mathrm{RFD}_{\max }$ variables, regardless of the hand dominance or age group. While for the variable $\mathrm{I}_{\mathrm{mp}} \mathrm{F}_{50 \% \mathrm{max}}$, in the age groups from 35.0 to 49.9 and from 50.0 to 69.9, the first tested try for both hands should be considered, in 14.0 to 19.9 years group the second try should be taken into consideration, and in 20.0 to 34.9 age range, the better result of the non-dominant hand is the first try, and of the dominant is the second try.
\end{abstract}

Key words: HAND GRIP / MAXIMUM FORCE / EXPLOSIVE FORCE / CRITERION ENDURANCE / FORCE IMPULSE

\section{INTRODUCTION}

The complex anatomical and functional structure of the hand is mostly directed for the assignment of catching and holding as the dominant motoric function of this part of the hand (Fernandes et al., 2014).

Former research have dealt with various functional and motoric characteristics of the hand as a segment of the arm, as well as the attempt of identifying different biomechanical aspects of the production of the hand grip force characteristics (Bohannon, 2001; Nicolay and Walker, 2005; Допсаj et al., 2011; Fernandes et al., 2014). It has been determined that the dominant hand is around $10 \%$ stronger than the non-dominant hand (Hager-Ros and Rosblad, 2002; Кљајић et al., 2012), and that men reach the abso- lute maximum force values in the forth decade of life, those values decrease afterwards (Massy-Westropp et al., 2011). It has been confirmed that the children's and adolescent's maximum hand grip force can be useful for tracking biological development as well as for function of total muscular development evaluation (Bohannon, 2001; Sartorio et al., 2002; Wind et al., 2010). In the fields of epidemiology and gerontology it is used for examining the effect of older generation aging (Kerr et al., 2006), and it is also a significant indicator of health parameters of the grown-ups, such as density of the bone mass or the protein loss (Foo et al., 2007).

By analyzing the data from the available literature, it can be concluded that the examined phenomena of the hand contractility are mostly linked to the 
maximum force (Müller et al., 2000; Dopsaj et al., 2007; Aadahl et al., 2011), and the small number of research were realized in accordance with the explosive force (Demura et al., 2003; Dopsaj et al., 2009a), as well as in accordance with the endurance characteristics when producing force (Кљајић et al., 2012). The lack of scientific information about the metrological characteristics of different contractile abilities of thehand muscles which are obtained through the mentioned "Hand Grip" test, compared to the age of the examinees, is noticeable, especially when taking into consideration the fact that during the process of growing up (preadolescent, adolescent and post-adolescent period) and during the aging process, the contractile abilities of the muscles are changing (Aadahl et al., 2011).

No matter which scientific discipline it is being applied in, the fact is that the "Hand grip" test is extremely applicable, simple and informative when applying the standardized measuring procedure. It is necessary to define both the new innovative values of the very test as well as the contractile characteristics which are measured by its application, all in order to improve the technological procedures of obtaining the valid and reliable information that indicate the physical health and specialized muscular function of the upper part of the body, i.e. the general indication about the muscular functions of the entire body of the population of interest. For the needs of defining such expert system, it is necessary to form a huge data base with referential values, where the methodological procedure of forming data base requires initial definition of the healthy population conditions of both genders in every age category (Hager-Ros and Rosblad, 2002; Dopsaj et al., 2009b). Such piece of information is essential when it comes to criterion and normative values and it is used for the needs of deciding algorithms, as well as more precise interpretations of the testing results, in the sense of comparison of both top athletes and recreationists, but also of the rest of the population, no matter whether they are healthy, injured or ill people that don't do sports (Desrosiers et al., 1995; Müller et al., 2000; Bohannon, 2001; Kerr et al., 2006; Gallup et al., 2007; Dopsaj et al., 2007; Dopsaj et al., 2009a; Ivanovic et al., 2009; Dhara et al., 2009; Beloosesky et al., 2010; Carrasco et al., 2010).

The subject of this research is to examine different contractile characteristics of a hand. The aim of the research was to determine the reliability and quantitative descriptive indicators of different contractile functions of the male hand in relation to the maximum and explosive force, as well as criterion endurance of producing force in the function of motoric and functional dominance and age. Considering the already tested space of contractile characteristics realiability of both lower muscles and upper extremities from the aspect of force and explosive force where the results showed the high level of reliability (Blazevich et al., 2002; Demura et al., 2003; Ivanovic and Dopsaj, 2013; Jenkins et al., 2014), similar results can be expected in the space of hand muscles force and explosive force, and positive results in the space of hand muscle force impulse can be assumed.

\section{METHODS}

In case of this research, for the purpose of measuring the contractile characteristics of the muscular force, the quantitative approach of sampling the information has been applied, by the dynamometry method and by testing in isometric conditions of straining (Допсај, 2010). As a primary research method, the laboratory testing with the usage of the "Hand Grip" standardized test has been used (Dopsaj et al., 2007; Ivanovic et al., 2009; Допсај et al., 2011). The analytical and statistical methods would be applied as a basic cognitive method, as well as the method of induction,i.e. total induction.

\section{The research sample}

The sample included 269 male examinees ranging from 14.0 to 69.9 years old, out of which 59 examinees aging from 14.0 to 19.9 years old - group $\mathrm{I}(\mathrm{BH}=$ $181.9 \pm 6.1 \mathrm{~cm}, \mathrm{BW}=77.9 \pm 10.57 \mathrm{~kg}, \mathrm{BMI}=23.5 \pm 2.7$ $\left.\mathrm{kg} / \mathrm{m}^{2}\right), 123$ examinees aging from 20.0 to 34.9 years old - group II $(\mathrm{BH}=182.8 \pm 6.9 \mathrm{~cm}, \mathrm{BW}=86.1 \pm 14.4$ $\left.\mathrm{kg}, \mathrm{BMI}=25.7 \pm 3.4 \mathrm{~kg} / \mathrm{m}^{2}\right), 47$ examinees aging from 35.0 to 49.9 years old - group III $(\mathrm{BH}=181.7 \pm 7.2 \mathrm{~cm}$, $\left.\mathrm{BW}=87.5 \pm 12.4 \mathrm{~kg}, \mathrm{BMI}=26.5 \pm 3.41 \mathrm{~kg} / \mathrm{m}^{2}\right)$ and 40 examinees aging from 50.0 to 69.9 years old - group $\mathrm{IV}(\mathrm{BH}=180.3 \pm 4.77 \mathrm{~cm}, \mathrm{BW}=86.7 \pm 11.8 \mathrm{~kg}, \mathrm{BMI}=$ $26.6 \pm 3.16 \mathrm{~kg} / \mathrm{m}^{2}$ ). Twenty examinees reported their left hand as their dominant one. The examinees were chosen by a simple random sample from the sports and general population. They all were familiar with the methods of testing and they voluntarily took part in the examination. The examination was carried out according to the terms of Helsinki declaration and 
with the approval of Ethic Committee of the Faculty of Sport and Physical Education University of Belgrade.

\section{Measurament procedure}

The examinees were tested by the application of the standardized measurement procedure which was previously described as follows: in a sitting position, with the arm either outstretched mildly flexed which is placed in the easily abducted position (Допсај et al., 2011; Кљајић et al., 2012). The procedure was as follows - after the singly basic 3-minute warm-up (shaping and stretching exercises) each of the examinees was explained the testing procedure. After that, they were introduced to the test by realizing 3 to 4 initial tryouts of the hand grip on lower force intensities, i.e. they tried to realize the endurance of each hand alternately in duration of 10 seconds with the arbitrarily selected force ranging from 150 to $200 \mathrm{~N}$. After that, each examinee performed one try of the maximum hand grip (both with dominant and non-dominant hand) for the sake of getting familiar with the testing procedure and in the function of the final and specific warming up phase as well.

After the 2 to 3-minute break, the examinees did the test following the protocol - firstly, they realized two alternate measurements of maximum muscular hand grip force of both hands, on the mark of the measurer (the examinee was free to choose which hand he would do the test with first) in order to define the level which is $100 \%$ of the given contractile ability (maximum contraction duration is 2 seconds). The break between every testing tryout was at least 1 minute long.

After that, in the latter part of the procedure, after 2 to 3-minute break, the measuring of the production of the given force capacity ensued (durability of the isometric muscle force production), i.e. the time interval during which the examinees could maintain the given force level at $50 \%$ of the maximum was measured, according to the before mentioned procedure (Markovic et al., 2016). The assignment of the examinees was to keep the defined level of the force in the longest time interval as possible up until willing to quit by looking at the monitor which showed the level of force. The realization time of the given force was measured by a software, and the task of the measurer was to watch the screen with the examinee and to correct the examinee according to the force realization level, as well as to verbally motivate the examinee to endure the given task in as longer time interval as possible. Once the examinee couldn't realize the defined level of force anymore, i.e. when his performance fell below $45 \%$ of the maximum, the attempt was stopped, and the software recorded the total time of the endurance in the given range. After the 5-minute break, the same test was realized with the other hand, and after the break of at least 10 minutes, the endurance test for both hands was repeated, following the same procedure.

The dynamometric probe which is fixed to the construction and specially intended for the realization of the "Hand Grip" testing was used (Markovic et al., 2016), while the frequency of the selection i.e. information sampling was realized on the level of $500 \mathrm{~Hz}$, and with the help of the software used for analyzing data, called "Isometrics" (ver. 3.1.1).

\section{Variables}

The tested space was defined in accordance with the three variables muscular hand force as follows: the aspect of maximum force (shown in $\mathrm{N}$ ), maximum explosive force (shown in $\mathrm{N} / \mathrm{s}$ ), and the endurance in muscular force production, i.e. the temporal aspect of detecting the given force percentage (shown in Ns).

For the purpose of this examination, the following variables were used:

1. Maximum muscular hand grip force $-\mathrm{F}_{\max }$ : of the dominant hand $\left(\mathrm{F}_{\max } \mathrm{D}\right)$ and the non-dominant hand $\left(\mathrm{F}_{\max } \mathrm{ND}\right)$, through the first (1) and the second (2) attempt, shown in Newtons $(\mathrm{N})$;

2. Maximum value of the explosive force - RFD$\max ^{2}$ : absolute value of the dominant hand $\left(\mathrm{RFD}_{\max } \mathrm{D}\right)$ and non-dominant hand $\left(\mathrm{RFD}_{\max } \mathrm{ND}\right)$, through the first (1) and second (2) attempt, shown in Newton per second $(\mathrm{N} / \mathrm{s})$.

3. The muscular force impulse, endurance of the hand grip force, achieved on the level of $50 \%$ of $\mathrm{F}_{\max }-\mathrm{I}_{\operatorname{mp}} \mathrm{F}_{50 \% \max }$ (calculated as a product of the force level $\mathrm{F}_{50 \% \max }$ and the performed time during endurance on the mentioned force level): of the dominant hand $\left(\mathrm{I}_{\mathrm{mp}} \mathrm{F}_{50 \% \max } \mathrm{D}\right)$ and the non-dominant hand $\left(\mathrm{I}_{\mathrm{m}-}\right.$ $\left.\mathrm{F}_{50 \% \max } \mathrm{ND}\right)$, through first (1) and the second (2) attempt, which is shown in Newton-seconds (Ns). 


\section{Statistical analysis}

All results were firstly analyzed by the application of the basic descriptive statistical method where the following was calculated: central tendencies measures (arithmetic mean) and the dispersion measures (standard deviation) and the variation coefficient $\left(\mathrm{C}_{\mathrm{v}} \%\right)$. The data was processed by the Student's $t$ test for the dependent samples. After that, the linear regressive analyses, as well as the analyses of the similarities of the variable pairs, were calculated, i.e. the parameters of the reliability were calculated-Intraclass Correlation Coefficient (ICC) (Hair et al., 1998). All statistical analyses were carried out with the help of software package "SPSS 19.0", while for the level of the statistical significance, the value $\mathrm{p}<0.05$ was used.

\section{RESULTS}

The average values of muscular hand grip characteristics for the dominant and non-dominant hand of the whole sample were $501.8 \pm 97.1 \mathrm{~N}$ and $534.4 \pm 100.2 \mathrm{~N}$ for $\mathrm{F}_{\text {max }}, 1837.0 \pm 446.2 \mathrm{~N} / \mathrm{s}$ and $1984.8 \pm 494.7 \mathrm{~N} / \mathrm{s}$ for $\mathrm{RFD}_{\max }$, and 13537.4 \pm 5511.4 Ns and $14458.6 \pm 6600.8 \mathrm{Ns}$ for $\mathrm{I}_{\mathrm{mp}} \mathrm{F}_{50 \% \max }$.

The Table 1. shows the results of the both attempts of the tested variables of both the dominant and non-dominant hand in the function of age groups of the examinees. It was noticed that the highest measured $\mathrm{F}_{\max }$ of the hand grip of the non-dominant hand which was obtained from the II group for variable $\mathrm{F}_{\max } \mathrm{ND} 2$, while the lowest level of force was measured in the I group for the variable $\mathrm{F}_{\max } \mathrm{ND}$. In accordance with the $\mathrm{F}_{\max }$ indicators of the dominant hand, it can be noticed that the highest measured hand grip force which was determined in the II group for the variable $\mathrm{F}_{\max } \mathrm{D}$ 2, while the lowest force measured in the I group for the variable $\mathrm{F}_{\max } \mathrm{D} 1$.
When it comes to the RFD ${ }_{\text {max }}$ variable, the results have shown that the highest explosive hand grip force of the non-dominant hand was measured in II group for variable $\mathrm{RFD}_{\max } \mathrm{ND}$ 2, while the lowest level was measured in the IV group for the variable $\mathrm{RFD}_{\max } \mathrm{ND} 2$. In relation to the obtained $\mathrm{RFD}_{\max }$ values of the dominant hand one can point out that the highest level of the explosive hand grip force was measured in the II group for the variable $\mathrm{RFD}_{\max } \mathrm{D} 2$, while the lowest measured results were found in IV group for the RFD ${ }_{\text {max }} \mathrm{D} 1$ variable.

In accordance with the $\mathrm{I}_{\mathrm{mp}} \mathrm{F}_{50 \% \max }$ variables, the results have shown that the greatest impulse of the hand grip force of the non-dominant hand of the $50 \%$ below maximum was measured in group III for the variable $\mathrm{I}_{\mathrm{mp}} \mathrm{F}_{50 \% \max } \mathrm{ND}$, and the lowest level was measured in the I group for the variable $\mathrm{I}_{\mathrm{mp}} \mathrm{F}_{50 \% \text { - }}$

ND1. The highest measured impulse of the hand grip force of the dominant hand was pointed out in III group for the variable $\mathrm{I}_{\operatorname{mp}} \mathrm{F}_{50 \% \max } \mathrm{D} 1$, while the lowest one was measured in I group for the variables $\mathrm{I}_{\text {mp }} \mathrm{F}_{50 \% \max } \mathrm{D} 1$.

In relation to the established variations of the results, as well as their homogeneity measures, the results of the variation coefficient of the reached levels of the maximum force are within the $16.8 \%$ to $20.7 \%$ range, while the explosive level ranges from $19.4 \%$ to $29.8 \%$ which shows that the measured results $\mathrm{F}_{\max }$ and $\mathrm{RFD}_{\max }$ belong to the homogenous group of examinees, no matter the age. However in relation to the variation of measured results of the endurance testing while producing the muscular force, the $\mathrm{Cv} \%$ value ranges from 30.6 for $\mathrm{I}_{\mathrm{mp}} \mathrm{F}_{50 \% \text { max }} \mathrm{D} 2$ in the group IV, to the value of Cv\% 58.0 for $\mathrm{I}_{\mathrm{mp}} \underset{50 \% \max }{\mathrm{ND}} \mathrm{N} 1$ in the group I (Table 1). Although the determined level of the variation is about $30 \%$ above the optimal value, which means that it belongs to the non-homogenous category, it is placed below the value of $60 \%$, which satisfies the conditions for the usage of the statistical analysis in further phase of parametric statistics. 
Marković R. M. et al., Reliability of measuring various contractile functions..., PHYSICAL CULTURE 2018; 72 (1): 5-48

Table 1. Descriptive statistics of the tested variables

\begin{tabular}{|c|c|c|c|c|c|c|c|c|c|c|c|c|}
\hline Age groups: & & I & & & II & & & III & & & IV & \\
\hline Variables & Mean & $\begin{array}{l}\text { Std. } \\
\text { Dev. }\end{array}$ & Cv\% & Mean & $\begin{array}{l}\text { Std. } \\
\text { Dev. }\end{array}$ & Cv\% & Mean & Std. Dev. & Cv\% & Mean & Std. Dev. & Cv\% \\
\hline $\mathrm{F}_{\max } \mathrm{ND} 1(\mathrm{~N})$ & 462.8 & 87.6 & 18.9 & 519.6 & 98.0 & 18.9 & 507.9 & 105.3 & 20.7 & 481.2 & 87.1 & 18.1 \\
\hline $\mathrm{F}_{\max } \mathrm{ND} 2(\mathrm{~N})$ & 474.2 & 87.9 & 18.5 & 529.0 & 105.8 & 20.0 & 520.5 & 107.4 & 20.6 & 483.5 & 87.3 & 18.1 \\
\hline $\mathrm{RFD}_{\max } \mathrm{ND} 1(\mathrm{~N} / \mathrm{s})$ & 1813.2 & 493.0 & 27.2 & 1960.8 & 585.0 & 29.8 & 1822.5 & 428.6 & 23.5 & 1627.9 & 315.7 & 19.4 \\
\hline $\mathrm{RFD}_{\max } \mathrm{ND} 2(\mathrm{~N} / \mathrm{s})$ & 1859.7 & 441.0 & 23.7 & 1972.8 & 581.0 & 29.4 & 1893.7 & 446.2 & 23.6 & 1621.6 & 316.6 & 19.5 \\
\hline $\mathrm{I}_{\mathrm{mp}} \mathrm{F}_{50 \% \max } \mathrm{ND} 1(\mathrm{Ns})$ & 8203.9 & 4757.2 & 58.0 & 13970.3 & 6562.2 & 47.0 & 15552.3 & 7751.3 & 49.8 & 15317.7 & 6431.1 & 42.0 \\
\hline $\mathrm{I}_{\mathrm{mp}} \mathrm{F}_{50 \% \max } \mathrm{ND} 2(\mathrm{Ns})$ & 10555.6 & 4369.5 & 41.4 & 13685.9 & 5537.4 & 40.5 & 14770.2 & 7001.3 & 47.4 & 15137.8 & 5137.2 & 33.9 \\
\hline $\mathrm{F}_{\max } \mathrm{D} 1(\mathrm{~N})$ & 478.1 & 80.5 & 16.8 & 554.6 & 106.1 & 19.1 & 534.7 & 107.9 & 20.2 & 503.0 & 92.4 & 18.4 \\
\hline $\mathrm{F}_{\max } \mathrm{D} 2(\mathrm{~N})$ & 497.5 & 87.0 & 17.5 & 566.2 & 105.9 & 18.7 & 557.6 & 112.0 & 20.1 & 516.1 & 95.9 & 18.6 \\
\hline $\mathrm{RFD}_{\max } \mathrm{D} 1(\mathrm{~N} / \mathrm{s})$ & 1937.8 & 471.6 & 24.3 & 2087.7 & 565.5 & 27.1 & 1970.3 & 456.7 & 23.2 & 1742.6 & 385.3 & 22.1 \\
\hline $\mathrm{RFD}_{\max } \mathrm{D} 2(\mathrm{~N} / \mathrm{s})$ & 2011.0 & 487.4 & 24.2 & 2119.0 & 614.1 & 29.0 & 2015.4 & 470.0 & 23.3 & 1794.0 & 407.4 & 22.7 \\
\hline $\mathrm{I}_{\mathrm{mp}} \mathrm{F}_{50 \% \max } \mathrm{D} 1(\mathrm{Ns})$ & 9516.7 & 4940.1 & 51.9 & 15101.5 & 7109.4 & 47.1 & 16845.1 & 7717.4 & 45.8 & 16371.2 & 6636.4 & 40.5 \\
\hline $\mathrm{I}_{\mathrm{mp}} \mathrm{F}_{50 \% \max } \mathrm{D} 2(\mathrm{Ns})$ & 11685.4 & 4960.8 & 42.5 & 15351.7 & 6150.9 & 40.1 & 15845.5 & 6273.8 & 39.6 & 14798.1 & 4529.9 & 30.6 \\
\hline
\end{tabular}

In relation to the results of the differences in average values of the tested variables in the function of the tested tryouts (Table 2), it is established that the differences in results of the first and the second measurement of ten couples of the variables is highly statistically significant no matter the age group, ranging from $\mathrm{t}=-2.015$ and $\mathrm{p}=0.049$ for $\mathrm{F}_{\max } \mathrm{ND}$ for the III age group, to $\mathrm{t}=-4.115$ and $\mathrm{p}=0.000$ for $\mathrm{F}_{\max } \mathrm{D}$ for group I. The statistical significance wasn't established with thirteen variables i.e. their results range from $t=$ -1.919 and $\mathrm{p}=0.061$ for $\mathrm{RFD}_{\max } \mathrm{ND}$ in III age group to $t=-0.050$ and $p=0.961$ for $I_{\text {mp }} F_{50 \% \text { max }}$ ND in IV age group.

Table 2. The results of the differences analysis ( $t$ test)

\begin{tabular}{|c|c|c|c|c|c|c|c|c|}
\hline Age group: & \multicolumn{2}{|c|}{ I } & \multicolumn{2}{|c|}{ II } & \multicolumn{2}{|c|}{ III } & \multicolumn{2}{|c|}{ IV } \\
\hline Variables: & $\mathrm{t}$ & $\mathrm{p}$ & $\mathrm{t}$ & $\mathrm{p}$ & $\mathrm{t}$ & $\mathrm{p}$ & $\mathrm{t}$ & $\mathrm{p}$ \\
\hline $\mathrm{F}_{\max } \mathrm{ND} 1(\mathrm{~N}) \& \mathrm{~F}_{\max } \mathrm{ND} 2(\mathrm{~N})$ & -3.172 & 0.002 & -2.266 & 0.025 & -2.015 & 0.049 & -0.553 & 0.583 \\
\hline $\mathrm{RFD}_{\max } \mathrm{ND} 1(\mathrm{~N} / \mathrm{s}) \& \mathrm{RFD}_{\max } \mathrm{ND} 2(\mathrm{~N} / \mathrm{s})$ & -2.374 & 0.021 & -0.482 & 0.631 & -1.919 & 0.061 & 0.305 & 0.762 \\
\hline $\mathrm{I}_{\mathrm{mp}} \mathrm{F}_{50 \% \max } \mathrm{ND} 1(\mathrm{Ns}) \& \mathrm{I}_{\mathrm{mp}} \mathrm{F}_{50 \% \max } \mathrm{ND} 2(\mathrm{Ns})$ & -1.848 & 0.074 & 0.300 & 0.765 & -0.857 & 0.402 & -0.050 & 0.961 \\
\hline $\mathrm{F}_{\max } \mathrm{D} 1(\mathrm{~N}) \& \mathrm{~F}_{\max } \mathrm{D} 2(\mathrm{~N})$ & -4.115 & 0.000 & -3.267 & 0.001 & -3.837 & 0.000 & -2.788 & 0.008 \\
\hline $\mathrm{RFD}_{\max } \mathrm{D} 1(\mathrm{~N} / \mathrm{s}) \& \mathrm{RFD}_{\max } \mathrm{D} 2(\mathrm{~N} / \mathrm{s})$ & -2.917 & 0.005 & -1.409 & 0.161 & -1.820 & 0.075 & -1.903 & 0.064 \\
\hline $\mathrm{I}_{\mathrm{mp}} \mathrm{F}_{50 \% \max } \mathrm{D} 1(\mathrm{Ns}) \& \mathrm{I}_{\mathrm{mp}} \mathrm{F}_{50 \% \max } \mathrm{D} 2(\mathrm{Ns})$ & -2.229 & 0.033 & -1.351 & 0.183 & -0.471 & 0.643 & 2.510 & 0.018 \\
\hline
\end{tabular}

Table 3. shows the results of the reliability in accordance to the questioned variables and age groups. It has been determined that the reliability level of the each questioned contractive characteristic of the hand in the function of the age group is highly statistically significant ( $\mathrm{p}=0.000$ for every variable pair tested). The ICC value of $\mathrm{F}_{\text {max }}$ ranges from 0.938 to 0.977 , for $\mathrm{RFD}_{\max }$ from 0.903 to 0.971 , and for $\mathrm{I}_{\mathrm{mp}} \mathrm{F}_{50 \% \max }$ from 0.747 to 0.943 . 
Table 3. Results of the reliability (Intraclass Correlation Coefficient)

\begin{tabular}{|c|c|c|c|c|c|c|c|c|}
\hline \multirow[b]{2}{*}{ Variables: } & \multirow{2}{*}{$\begin{array}{l}\text { Age } \\
\text { group: }\end{array}$} & \multirow{2}{*}{$\begin{array}{l}\text { Intraclass } \\
\text { Correlation } \\
\text { Coefficient }\end{array}$} & \multicolumn{2}{|c|}{ 95\% Conf. Inte. } & \multicolumn{4}{|c|}{ F Test with True Value 0} \\
\hline & & & $\begin{array}{l}\text { Lower } \\
\text { Bound }\end{array}$ & $\begin{array}{l}\text { Upper } \\
\text { Bound }\end{array}$ & Value & df1 & df 2 & $\mathrm{p}$ \\
\hline \multirow{4}{*}{$\begin{array}{c}\mathrm{F}_{\max } \mathrm{ND} 1(\mathrm{~N}) \\
\& \\
\mathrm{~F}_{\max } \mathrm{ND} 2(\mathrm{~N})\end{array}$} & I & 0.971 & 0.944 & 0.984 & 39.599 & 58 & 58 & 0.000 \\
\hline & II & 0.944 & 0.920 & 0.961 & 18.545 & 122 & 122 & 0.000 \\
\hline & III & 0.956 & 0.918 & 0.976 & 23.884 & 46 & 46 & 0.000 \\
\hline & IV & 0.977 & 0.957 & 0.988 & 43.581 & 39 & 39 & 0.000 \\
\hline \multirow{4}{*}{$\begin{array}{c}\mathrm{RFD}_{\max } \mathrm{ND} 1(\mathrm{~N} / \mathrm{s}) \\
\& \\
\mathrm{RFD}_{\max } \mathrm{ND} 2(\mathrm{~N} / \mathrm{s})\end{array}$} & I & 0.971 & 0.950 & 0.983 & 37.513 & 58 & 58 & 0.000 \\
\hline & II & 0.941 & 0.915 & 0.959 & 16.798 & 122 & 122 & 0.000 \\
\hline & III & 0.903 & 0.824 & 0.946 & 10.854 & 46 & 46 & 0.000 \\
\hline & IV & 0.956 & 0.917 & 0.977 & 22.411 & 39 & 39 & 0.000 \\
\hline \multirow{4}{*}{$\begin{array}{c}\mathrm{I}_{\operatorname{mp}} \mathrm{F}_{50 \% \max } \mathrm{ND} 1(\mathrm{Ns}) \\
\& \\
\mathrm{I}_{\operatorname{mp}} \mathrm{F}_{50 \% \max } \mathrm{ND} 2(\mathrm{Ns})\end{array}$} & I & 0.761 & 0.509 & 0.884 & 4.430 & 30 & 30 & 0.000 \\
\hline & II & 0.875 & 0.780 & 0.929 & 7.892 & 49 & 49 & 0.000 \\
\hline & III & 0.943 & 0.858 & 0.977 & 17.313 & 19 & 19 & 0.000 \\
\hline & IV & 0.771 & 0.514 & 0.891 & 4.251 & 29 & 29 & $\mathbf{0 . 0 0 0}$ \\
\hline \multirow{4}{*}{$\begin{array}{c}\mathrm{F}_{\max } \mathrm{D} 1(\mathrm{~N}) \\
\& \\
\mathrm{~F}_{\max } \mathrm{D} 2(\mathrm{~N})\end{array}$} & I & 0.938 & 0.858 & 0.969 & 20.340 & 58 & 58 & 0.000 \\
\hline & II & 0.961 & 0.941 & 0.974 & 27.667 & 122 & 122 & 0.000 \\
\hline & III & 0.954 & 0.884 & 0.978 & 27.937 & 46 & 46 & 0.000 \\
\hline & IV & 0.970 & 0.935 & 0.985 & 38.865 & 39 & 39 & 0.000 \\
\hline \multirow{4}{*}{ 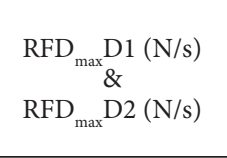 } & I & 0.953 & 0.912 & 0.973 & 23.732 & 58 & 58 & 0.000 \\
\hline & II & 0.954 & 0.934 & 0.968 & 21.963 & 122 & 122 & 0.000 \\
\hline & III & 0.964 & 0.934 & 0.980 & 28.735 & 46 & 46 & 0.000 \\
\hline & IV & 0.948 & 0.901 & 0.973 & 20.566 & 39 & 39 & 0.000 \\
\hline \multirow{4}{*}{$\begin{array}{l}\mathrm{I}_{\mathrm{mp}} \mathrm{F}_{50 \% \max } \mathrm{D} 1(\mathrm{Ns}) \\
\& \\
\mathrm{I}_{\mathrm{mp}} \mathrm{F}_{50 \% \max } \mathrm{D} 2(\mathrm{Ns})\end{array}$} & I & 0.769 & 0.515 & 0.889 & 4.753 & 30 & 30 & 0.000 \\
\hline & II & 0.747 & 0.557 & 0.856 & 4.002 & 49 & 49 & 0.000 \\
\hline & III & 0.894 & 0.732 & 0.958 & 9.104 & 19 & 19 & 0.000 \\
\hline & IV & 0.836 & 0.632 & 0.925 & 7.017 & 29 & 29 & 0.000 \\
\hline
\end{tabular}

By linear regressive analysis (Table 4, Charts 1 to 6), regressive models of the testing reliability are defined i.e. models of the linear regressive equations of all the tested variables for all ages. Graphs show the results of the linear regressive analysis in relation to the testing (Test 1 and 2) for the $\mathrm{F}_{\text {max }}$ variable in the function of the non-dominant (Chart 1) and dominant hand (Chart 2), for the variable $\mathrm{RFD}_{\max }$ in the function of the non-dominant (Chart 3) and dominant hand (Chart 4), and the $\mathrm{I}_{\mathrm{mp}} \mathrm{F}_{50 \% \max }$ variable in the function of the non-dominant (Chart 5) and

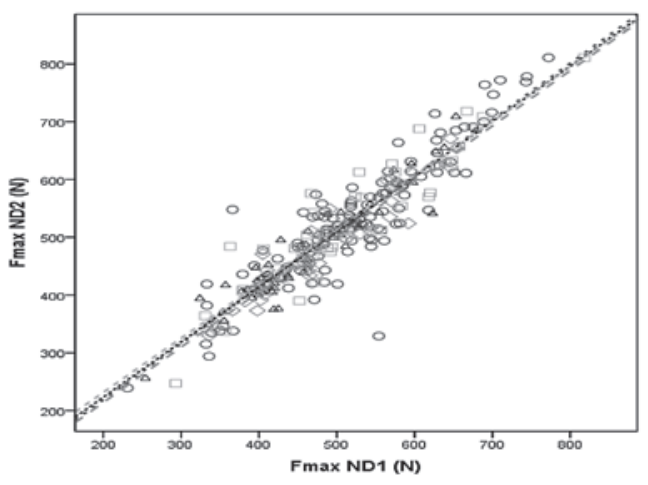

Chart 1 dominant hand (Chart 6). For the $\mathrm{F}_{\max }$ variable the range of the determination coefficient $\left(\mathrm{R}^{2}\right)$ for dominant hand is $0.826-0.903$, and for non-dominant hand $0.811-0.912$. The second variable $\mathrm{RFD}_{\max }$ ranges from 0.826-0.871 for dominant hand and 0.692-0.910 for non-dominant hand, while the $\mathrm{I}_{\mathrm{mp}} \mathrm{F}_{50 \% \max }$ variable of the determination coefficient $\mathrm{R}^{2}$ ranges from 0.360-0.674 for dominant hand, and 0.401-0.808 for non-dominant hand (Table 4). All regressive models of reliability showed the high level of significance on the level of $\mathrm{p}=0.000$.

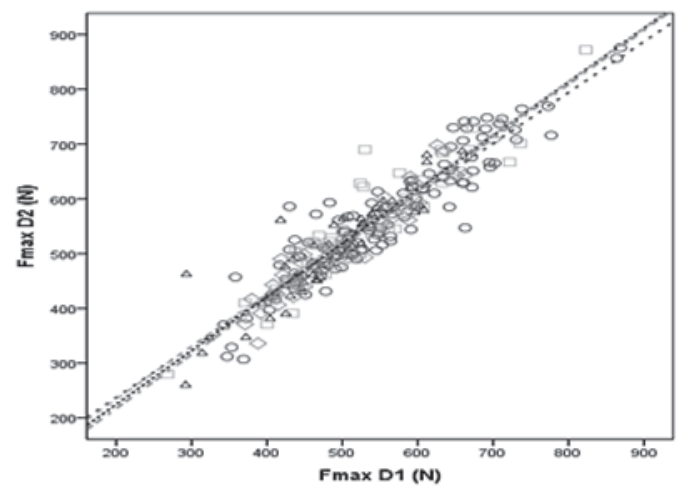

Chart 2

Linear regression $\mathrm{F}_{\max }$ for 1 and 2 attempt of non-dominant (Chart 1) and dominant hand (Chart 2) 


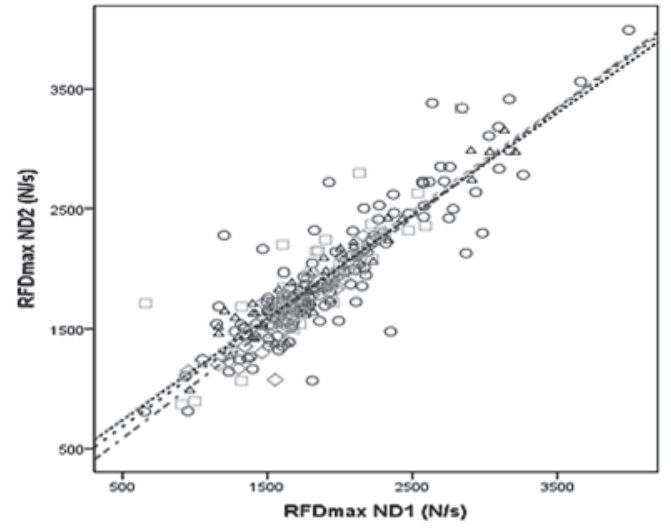

Chart 3

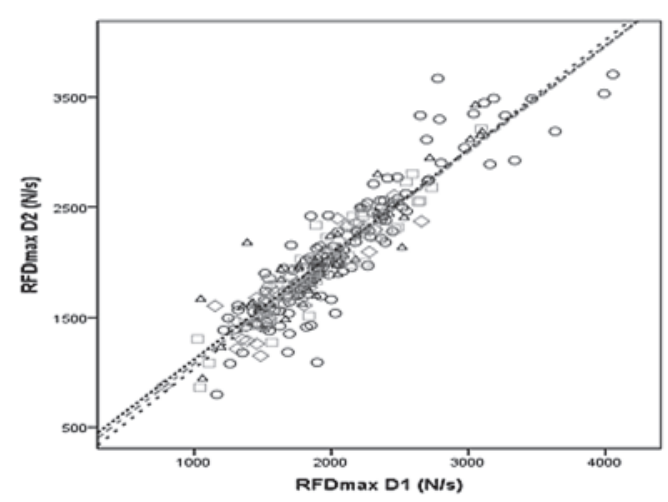

Chart 4

Linear regression $\mathrm{RFD}_{\max }$ for 1 and 2 attempt of non-dominant (Chart 3) and dominant hand (Chart 4)

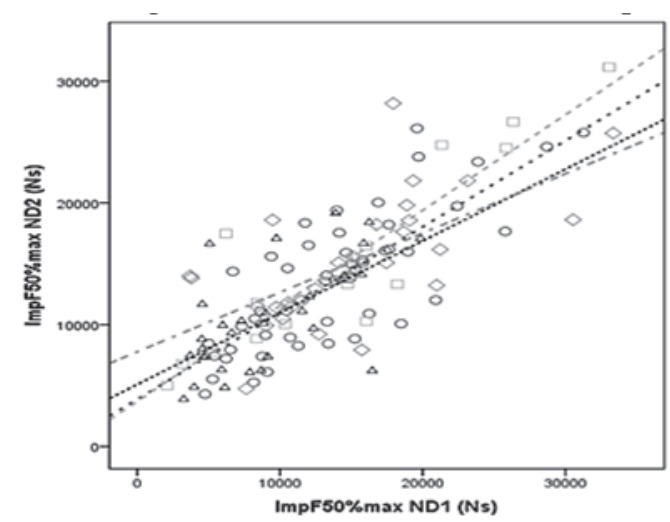

Charts 5

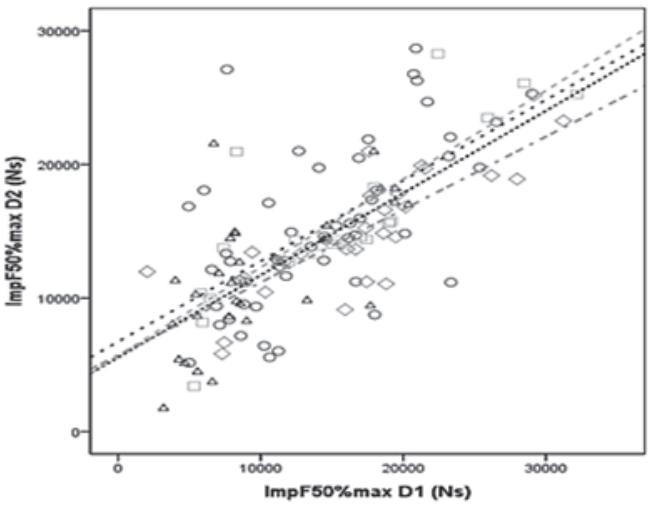

Chart 6

Linear regression $\mathrm{I}_{\mathrm{mp}} \mathrm{F}_{50 \% \max }$ for 1 and 2 attempt of non-dominant (Chart 5) and dominant hand (Chart 6)

${ }^{\star}$ Legend of the single result positions by age: $\Delta$ - age group from 14.0 to 19.9 - I age group; 0 - age group from 20.0 to 34.9 - II age group; $\square$ - age group from 35.0 to 49.9 - III age group; $\diamond$ - age group from 50.0 to 69.9 zoduHa - IV age group, and the same color points out the regressive lines also, i.e. blue for age group I; red for age group II; yellow for age group III; green for age group IV.

Table 4. The results of the defined models of the linear regressive equations

\begin{tabular}{|c|c|c|c|c|}
\hline \multirow{2}{*}{ Variables: } & \multicolumn{4}{|c|}{ A ge groups: } \\
\hline & $\mathrm{I}$ & II & III & IV \\
\hline \multirow{2}{*}{$\mathrm{F}_{\max } \mathrm{ND} 1(\mathrm{~N}) \& \mathrm{~F}_{\max } \mathrm{ND} 2(\mathrm{~N})$} & $y=0.955 \bullet x+32.237$ & $y=0.972 \cdot x+24.147$ & $y=0.938 \cdot x+43.905$ & $y=0.958 \cdot x+22.537$ \\
\hline & $R^{2}=0.904$ & $R^{2}=0.811$ & $R^{2}=0.846$ & $R^{2}=0.912$ \\
\hline \multirow{2}{*}{$\begin{array}{l}\mathrm{RFD}_{\max } \mathrm{ND} 1(\mathrm{~N} / \mathrm{s}) \& \\
\mathrm{RFD}_{\max } \mathrm{ND} 2(\mathrm{~N} / \mathrm{s})\end{array}$} & $y=0.853 \cdot x+312.324$ & $y=0.882 \cdot x+244.349$ & $y=0.866 \bullet x+315.077$ & $y=0.917 \cdot x+128.561$ \\
\hline & $R^{2}=0.910$ & $R^{2}=0.788$ & $R^{2}=0.692$ & $R^{2}=0.836$ \\
\hline \multirow{2}{*}{$\begin{array}{l}\mathrm{I}_{\mathrm{mp}} \mathrm{F}_{50 \% \max } \mathrm{ND} 1(\mathrm{Ns}) \& \\
\mathrm{I}_{\mathrm{mp}} \mathrm{F}_{50 \% \max } \mathrm{ND} 2(\mathrm{Ns})\end{array}$} & $y=0.589 \cdot x+5095.834$ & $y=0.708 \bullet x+3881.749$ & $y=0.785 \bullet x+3710.923$ & $y=0.488 \bullet x+7780.499$ \\
\hline & $R^{2}=0.401$ & $R^{2}=0.606$ & $R^{2}=0.808$ & $R^{2}=0.413$ \\
\hline \multirow{2}{*}{$F_{\max } \mathrm{D} 1(\mathrm{~N}) \& \mathrm{~F}_{\max } \mathrm{D} 2(\mathrm{~N})$} & $y=0.981 \cdot x+28.355$ & $y=0.928 \times x+51.338$ & $y=0.967 \cdot x+40.519$ & $y=0.986 x+20.174$ \\
\hline & $R^{2}=0.826$ & $R^{2}=0.865$ & $R^{2}=0.868$ & $R^{2}=0.903$ \\
\hline \multirow{2}{*}{$\begin{array}{l}\mathrm{RFD}_{\text {max }} \mathrm{D} 1(\mathrm{~N} / \mathrm{s}) \& \\
\mathrm{RFD}_{\max } \mathrm{D} 2(\mathrm{~N} / \mathrm{s})\end{array}$} & $y=0.950 \cdot x+169.398$ & $y=0.995 \cdot x+42.115$ & $y=0.960 \bullet x+123.024$ & $y=0.961 \bullet x+119.489$ \\
\hline & $R^{2}=0.846$ & $R^{2}=0.839$ & $R^{2}=0.871$ & $R^{2}=0.826$ \\
\hline \multirow{2}{*}{$\begin{array}{l}\mathrm{I}_{m p} F_{50 \% \max } \mathrm{D} 1(\mathrm{Ns}) \& \mathcal{D} \\
\mathrm{I}_{\operatorname{mp}} \mathrm{F}_{50 \% \max } \mathrm{D} 2(\mathrm{Ns})\end{array}$} & $y=0.615 \bullet x+5548.499$ & $y=0.603 \cdot x+6729.400$ & $y=0.661 \cdot x+5679.263$ & $y=0.545 \bullet x+5721.218$ \\
\hline & $R^{2}=0.427$ & $R^{2}=0.360$ & $R^{2}=0.674$ & $R^{2}=0.657$ \\
\hline
\end{tabular}




\section{DISCUSSION}

The examinations of the contractile characteristics of the hand muscles are of great importance in predicting the functional limitations and diagnosis of the neural disorders, and have a significant role in the evaluation of the general level of the contractile physical abilities development of both professional athletes and recreationists (Desrosiers et al., 1995; Rantanen et al., 1998; Bohannon, 2001; Wind et al., 2010; Koley et al., 2011). Research of this type present the permanently current field of interest of the scientific research in order to increase the fundus of the knowledge, and to perfect the testing procedures in diagnostics, therapeutic and professional means as well.

Besides higher statistically significant correlation when it comes to repetitive action of the testing, the statistically significant difference of the average values of the $\mathrm{F}_{\max }$ variables of the first and the second attempt of the dominant hand of all the age categories, and for the non-dominant hand as well in the first three tested groups (I, II, III age group)(Table 2 ). Other statistical analyses used to examine the reliability of measuring, showed the extremely high level of given characteristics of detection of maximum force $\left(\mathrm{F}_{\max }\right)$, of the hand grip of all the questioned groups on the ICC level from 0.944 to 0.977 for non-dominant hand, i.e. from 0.938 to 0.970 for the dominant hand (Table 3 ). The given results are in total confirmation with the previously determined standards in relation to the reliability of the standard tests of the hand grip force of 0.961 for the right hand and 0.950 for the left hand (Hamilton et al., 1994), and respectably in accordance with the higher reliability of the standard tests of force of other muscular groups ranging from ICC 0.97-1.00 for isometric squat position and leg pushing from the standing position (Blazevich et al., 2002), as well as for the standard leg thrust on the Cronbach's Alpha level of 0.989 (Ivanovic and Dopsaj, 2013). This way, the results showed that the usage of the isometric testing, in relation to the maximum hand grip force measurement is also reliable in the function among the male sex examinees of different age. It ought to be mentioned that because of the estimated statistically significant difference of the second measurement compared to the first measurement, the result of the second attempt, i.e. the result of the stronger attempt should be considered as a final result.
In the case of second tested variable, which measured the maximum level of explosive hand grip force $\mathrm{RFD}_{\text {max }}$, the statistically significant difference between attempts was estimated only in age group I, both in cases of dominant and non-dominant hand (Table 2 ). This can be explained by the omition of the previous experience of performing the same strainings and their initial unpreparedness for the task during their first attempt i.e. the higher acute neuro-motoric adaptability during their second attempt. Further statistical analysis have shown extremely high level of reliability of the given contractile characteristic RFDof hand grip in all of the tested age groups on ICC level from 0.903 to 0.971 for non-dominant hand, and from 0.948 to 0.964 for dominant hand (Table 3). As in the case of $\mathrm{F}_{\max }$ these results are in confirmation with the early established standards in relation to the reliability of methods for testing the explosive hand grip force where the ICC levels from 0.870 to 0.930 (Demura et al., 2003; Jenkins et al., 2014) i.e. in accordance with the high reliability of the standard tests of force of the other muscular groups leveled from 0.808 to 0.945 Cronbach's Alpha for the standard leg thrist (Ivanovic and Dopsaj, 2013). Based on former research and the given results of these tests it is obvious that the usage of the isometric testing, in relation to the measures of the maximum explosive force of the hand grip test, is valid in the function of the various groups and ages of men. One should mention that the statistically significant difference of the second measurement compared to the first is detected only in age group I for both hands. However, absolute differences in the average results obtain are seen in favor of the second attempt, and they are based on the descriptive statistics in all age groups, except for group IV for non-dominant hand, where the first attempt was better (Table 1). With all this in mind, one can propose the measurement of the final attempt of the explosive force, i.e. the result of the second attempt as the final result.

While in the third tested variable which measured the impulse of the maintaining of the force on the $50 \%$ from maximum - $\mathrm{I}_{\mathrm{mp}} \mathrm{F}_{50 \% \max }$ the significant difference between the first and the second attempt oftesting can be seen in I age group, but also in the IV age group for dominant hand only (Table 2 ). The important factor of this testis the usage of the sensory information i.e. the visual monitoring of maintenance of the assigned level of the force which is at $50 \%$ of maximum, and their compatibility (motoric 
control) with the muscular characteristic (muscular endurance), where in the disputed age categories one may come across the process of accelerated developmentor the degradation of the same, this being the cause of obtained results (Nicolay and Walker, 2005). Based on these results the statistically significant level of reliability of the detection of the $\mathrm{I}_{\mathrm{mp}} \mathrm{F}_{50 \% \max }$ hand grip can be seen in all tested age groups on the ICC level from 0.761 to 0.943 for non-dominant hand, and from 0.747 to 0.894 for dominant hand (Table 3). Functional muscular ability for manifestation of the assigned level of the force as a measure of endurance, expressed as a force impulse has not been much examined phenomena in the sports area (Nicolay and Walker, 2005; Кљајић et al., 2012). Besides statistically significant difference between the testing attempts $\mathrm{I}_{\mathrm{mp}} \mathrm{F}_{50 \% \max }$ only in the I and IV age group for dominant hand (Table 2), the differences in average accomplished results can be distinguished based on the results of the descriptive statistics (Table 1). Based on that, it can be recommended that the value which presents the higher endurance should be taken as a final result, but that in the III and IV age group the first testing attempt mainly presents the better result for both hands, while in the I age group it is the second one, and in the II aging group the mark of the better result of the non-dominant hand is the first, and of the dominant hand is the second attempt.

The high level of significance of the regressive models of testing reliability of the variables of all age groups has been established. One can say that the great amount of variety of the second measurement is explained through the first one and that is for $\mathrm{F}_{\max }$ ranging from $81 \%$ to $91 \%$, for $\mathrm{RFD}_{\text {max }}$ ranging from $69 \%$ to $91 \%$ and for $\mathrm{I}_{\mathrm{mp}} \mathrm{F}_{50 \% \max }$ ranging from $36 \%$ to $80 \%$. There by it is notice able that the obtained results of the linear regressive analysis for $\mathrm{F}_{\max }$ and $\mathrm{RFD}_{\text {max }}$ are for a bit lower than the values informer research which range from $96 \%$ to $99 \%$ for both variables (Giampaoli et al., 1999; Dopsaj et al.,2009b). Regressive models of reliability $\mathrm{I}_{\mathrm{mp}} \mathrm{F}_{50 \% \max }$ were not noticed as a matter of former interest, so the possibility of comparison is omitted. This way the possibility of the prediction of the optimal result of the measured contractile characteristics of the hand is enabled, as well as positioning of the actual examinee in the function of the defined population standards.

\section{CONCLUSION}

The hand grip presents the important method which can be used to diagnose the level of the functional ability of tested contractile properties of the hand as a basic manipulative segment which shows the basic condition of the muscular functions of the whole organism.

In accordance with the aim of the research, quantitative descriptive indicators which can serve as a means of comparing and determining the levels of development of the stated abilities of people of various level of training, various functional and health condition as well as of people with different stadiums of motoric or some other disorders, and therefore can gain the vast practice from many cognitive and practical aspects. One can state that the "Hand Grip" test can measure all of the three contractive characteristics of the hand - maximum and explosive force, endurance of the force of males from the age of 14.0 to 69.9 years.

Of course, as a final indicator of the contractive muscle characteristics, the value which shows the better score is taken into consideration. By omitting the previous experience of performing the similar straining and their initial motor in adaptability for the task, it is established that the representative value of the $\mathrm{F}_{\text {max }}$ and $\mathrm{RFD}_{\text {max }}$ variables is best shown by taking the second attempt into consideration, no matter the hand dominance or age group. For the variable $\mathrm{I}_{\operatorname{mp}} \mathrm{F}_{50 \% \max }$, after the $35^{\text {th }}$ year of age, it is common to take the first attempt for both hands, while for the youngest tested group, the second attempt should be taken as a definite means of testing. In the age of 20.0 to 34.9 , the indicator of the better result of the non-dominant hand is the first, and of the dominant hand is the second attempt.

\section{Acknowledgements}

The paper is a part of the project "Effects of the Applied Physical Activity on Locomotor, Metabolic, Psychosocial and Educational Status of the Population of the Republic of Serbia", number III47015, funded by the Ministry of Education, Science and Technological Development of the Republic of Serbia - Scientific Projects 2011 - 2018 Cycle. 


\section{REFERENCES:}

1. Aadahl, M., Beyer, N., Linneberg, A., Thuesen, B.H. \& Jørgensen, T. (2011). Grip strength and lower limb extension power in 19-71 years old Danish men and women: the Health 2006 study. BMJ Open, 1:10.

2. Beloosesky, Y., Weiss, A., Manasian, M. \& Salai, M. (2010). Handgrip strength of the elderly after hip fracture repair correlates with functional outcome. Disability and Rehabilitation, 32 (5), 367-673.

3. Blazevich, A., Gill, N. \& Newton, R. (2002). Reliability and validity of two isometic squat tests. Journal of Strength and Conditioning Research, 16(2), 298-304.

4. Bohannon, R.W. (2001). Dynamometer measurements of hand grip strength predict multiple outcomes. Percept Motor Skills, 93: 323-328.

5. Carrasco, L., Pradas, F., Floría, P., Martínez, A., Herrero, R. \& Juraldo, J. A. G. (2010). Grip strength in young Top-level table tennis players. International Journal of Table Tennis Sciences, 6, 64-66.

6. Demura, S., Yamaji, S., Nagasawa, Y., Sato, S., Minami, M. \& Yoshimura, Y. (2003). Reliability and gender differences of static explosive grip parameters based on force-time curves. The Journal of Sports Medicine and Physical Fitness, 43:28-35.

7. Desrosiers, J., Bravo, G., Hebert, R. \& Dutil, E. (1995). Normative data for grip strength of elderly men and women. The American Journal of Occupational Therapy, 49(7), 637-644.

8. Dhara, P.C., De, S., Pal, A., Sengupta, P. \& Roy, S. (2009). Assessment of hand grip strength of orthopedically challenged persons affected with upper extremity. Journal of Life Sciences, 1 (2), 121-127.

9. Dopsaj, M. (2010). Karakteristike F-t krive: Analitički i dijagnostički značaj u sportu. [Characteristics of F-t curve: Analytical and diagnostic significance in sport. In Serbian]. In R. Stanković (ED.). Proceedings of the XIV Scientific Conference „FIS COMMUNICATIONS 2010" in physical education, sport and recreation (pp 44-52). Niš:Faculty of sport and physical education.

10. Dopsaj, M., Ivanović, J., Blagojević, M., Koropanovski, N., Vučković, G., Janković, R. \& Miljuš, D. (2009a). Basic and specific characteristics of the hand grip explosive force and time parame- ters in different strength trained population. Brazilian Journal of Biomotricity, 3(2), 177-193.

11. Dopsaj, M., Ivanović, J., Blagojević, M. \& Vučković, G. (2009b). Descriptive, functional and sexual dimorphism of explosive isometric hand grip force in healthy university students in Serbia. FACTA UNIVERSITATIS: Series Physical Education and Sport, 7(2), 125-139.

12. Dopsaj, M., Kljajić, D., Eminović, F., Koropanovski, M., Dimitrijević, R., Stojković, I. (2011). Modelni pokazatelji karakteristika mišićne sile kod mladih i zdravih osoba pri motoričkom zadataku stisak šake, Pilot istraživanje. [Model indicators of the muscular strength characteristics of young and healthy persons in the motor assignment of hand grip, Pilot research. In Serbian]. Specijalna edukacija i rehabilitacija 10 (1), 15-36.

13. Dopsaj, M., Koropanovski, N., Vučković, G., Blagojević, M., Marinković, B. \& Miljuš, D. (2007). Maximal isometric hand grip force in well-trained university students in Serbia: Descriptive, functional and sexual dimorphic model. Serbian Journal of Sports Sciences, 1 (4), 138-147.

14. Fernandes, A.A., Natali, A.J., Vieira, B.C., Neves do Valle, M.A.A., Moreira, D.G., Massy-Westropp, N. \& Marins, B. (2014). The relationship between hand grip strength and anthropometric parameters in men. Archivos de Medicina del Deporte, 31(3), 160- 164.

15. Foo, L.H., Zhang, Q., Zhu, K., Ma, G., Greenfield, H. \& Fraser, D.R. (2007). Influence of body composition, muscle strength, diet and physical activity on total body and forearm mass in Chinese adolescent girls. The British Journal of Nutrition, 98(6), 1281-1287.

16. Gallupa, A.C., White, D.D. \& Gallup, G.G. (2007). Handgrip strength predicts sexual behavior, body morphology, and aggression in male college students. Evolution and Human Behavior, 28, 423-429.

17. Giampaoli, S., Ferrucci, L., Cecchi, F., Lo Noce, C., Poce, A., Dima, F., Santaquilani, A., Vescio, M.F. \& Menotti, A. (1999). Hand-grip strength predicts incident disability in non-disabled older men. Age and Ageing, 28, 283-288. 
18. Hager-Ros, C. \& Rosblad, B. (2002). Norms for grip strength in children aged 4-16 years. Acta Paedriatrica, 91 (6), 617-625.

19. Hair, J., Anderson, R., Tatham, R. \& Black, W. (1998). Multivariate Data Analysis(Fifth Ed.). Prentice - Hall, Inc., USA.

20. Hamilton, A., Balnave, R. \& Adams, R. (1994). Grip srrenght testing reliability. Journal of Hand Therapy, 7, 163-170.

21. Ivanovic, J., Koropanovski, N., Vuckovic, G., Jankovic, R., Miljus, D., Marinkovic, B. \& Dopsaj, M. (2009). Functional dimorphism and characteristics considering maximal hand grip force in top level athletes in the Republic of Serbia. Gazzetta Medica Italiana Archivio per le Scienze Mediche, 168(5), 297-310.

22. Ivanovic, J. \& Dopsaj, M. (2013). Reliability of force-time curve characteristics during maximal isometric leg press in differently trained high-level athletes. Measurement, 46, 2146-2154.

23. Kadir, E., Harmaa, A., Cetinb, A., Elmalia, N., Yologluc, S., Bostana, H. \& Sakaryaa, B. (2005). An investigation of hand dominance, average versus maximum grip strength, body mass index and ages as determinants for hand evaluation. Isokinetics and Exercise Science, 13: 223-227.

24. Kattel, B.P., Fredericks, T.K., Fernandez, J.E. \& Lee, D.C. (1996). The effect of upper-extremity posture on maximum grip strength. International Journal of Industrial Ergonomics, 18(5-6), 423-429.

25. Kerr, A., Syddall, H.E., Cooper, C., Turner, G.F., Briggs, R.S. \& Sayer, A.A. (2006). Does admission grip strength predict length of stay in hospitalized older patients?. Age and Ageing, 35(1), 82-84.

26. Kljajić, D., Eminović, F., Tgovčević, S., Dimitrijević, R., Dopsaj, M. (2012). Funkcionalni odnos nedominantne i dominantne ruke pri motoričkom zadatku - izdržljivost u sili stiska šake. [Functional relation of the non-dominant and dominant hand in the motor task - endurance in the force of the hand pressing. In Serbian] Specijalna edukacija i rehabilitacija, 11(1): 67-85.

27. Koley, S., Singh, S. \& Kaur, S. (2011). A study of arm anthropometric profile in Indian inter- university basketball players. Serbian Journal of Sports Sciences, 5 (1): 35-40.

28. Marković, M., Dopsaj, M. \& Kasum, G. (2016). Differences between contractile characteristics of wrestler's hand and control group of young, moderately active people. U S. Pantelic (Ed.) Proceedings of the XIX Scientific Conference „FIS COMMUNICATIONS 2016" in physical education, sport and recreation(pp 44-52). Niš, Faculty of sport and physical education.

29. Massy-Westropp, N., Gill, T., Taylor, A., Bohannon, R. \& Hill, C. (2011). Hand grip strength: age and gender stratified normative data in a population-based study. BMC Research Notes, 4, 127.

30. Müller, E., Benko, U., Raschner, C. \& Schwameder, H. (2000). Specific fitness training and testing in competitive sports. Medicine and Science in Sports and Exercise, 32(1), 216-220.

31. Nicolay, C.W. \& Walker, A.L. (2005). Grip strength and endurance: Influences of anthropometric variation, hand dominance, and gender. International Journal of Industrial Ergonomics, $35,605-618$.

32. Jenkins, N., Buckner, S., Bergstrom, H., Cochrane, K., Goldsmith, J., House, T., Johnson, G., Schmidt, R. \& Cramer, J. (2014). Reliability and relationships among hand grip strength, leg extensor strength and power, and balance in older men. Experimental Gerontology, 58, 47-50.

33. Rantanen, T., Masaki, K., Foley, D., Izmirlian, G., White, L. \& Guralnik, J. M. (1998). Grip strength changes over $27 \mathrm{yr}$ in Japanese-American men. Journal of Applied Physiology, 85(6), 2047-2053.

34. Sartorio, A., Lafortuna, C.L., Pogliaghi, S. \& Trecate, L. (2002). The impact of gender, body dimension and body composition on hand-grip strength in healthy children. Journal of Endocrinological Investigation, 25(5), 431-435.

35. Wind, A., Takken, T., Helders, P. \& Engelbert, R. (2010). Is grip strength a predictor for total muscle strength in healthy children, adolescents, and young adults?. European Journal of Pediatrics, 169, 281-287. 


\title{
FIABILIDAD DE MEDICIÓN DE DISTINTAS FUNCIONES CONTRÁCTILES DEL FLEXOR DE LOS DEDOS DE MANO EN HOMBRES DE DISTINTA EDAD
}

\begin{abstract}
Resumen
El objetivo de la investigación es establecer la fiabilidad de las pruebas de distintas funciones contráctiles de la mano de varón en dependencia de la dominación motriz-funcional y de la edad. La persona examinada toma la posición sedentaria con el brazo extendido o suavemente flexible, puesto en una ligera posición de abducción. Para las necesidades de medición se ha utilizado una sonda dinamométrica con las condiciones isométricas de tensión, fijada a una construcción especial. Se ha utilizado el software "Isometrics" (ver. 3.1.1), y la frecuencia de selección de datos se ha realizado en nivel de $500 \mathrm{~Hz}$. La muestra abarcó 269 personas examinadas del sexo masculino de 14.0 a 69,9 años de edad. Los resultados de la estadística descriptiva demostraron que en relación con la muestra examinada, los valores de la fuerza máxima demostrada (Fmax) para el brazo no dominante están en el rango de 462.8 до $529.0 \mathrm{~N}$, para la fuerza explosiva (RFDmax) en el rango de 1621.6 до 1972.8 N/s y para el impulso de la fuerza muscular (ImpF50\%max) de 8203.9 a 15552.3 Ns, mientras que los valores Fmax para el brazo dominante en el rango de 478.1 a $566.2 \mathrm{~N}$, para RFDmax en el rango de 1742.6 a $2119.0 \mathrm{~N} / \mathrm{s}$ y para ImpF50\%max de 9516.7 a 16845.1 Ns. Se estableció que se pueden medir fiablemente todas las tres características contráctiles examinadas de la mano, con lo que ICC está en el rango de 0.938 a 0.977 para Fmax, de 0.903 a 0.971 para RFDmax, y de 0.747 a 0.943 para ImpF50\%max. Como un valor representativo para las variables Fmax y RFDmax, sin tener en cuenta la dominación de un brazo o grupo de edad, debe tomarse la segunda prueba como mejor resultado, mientras que para la variable ImpF50\%max, en los grupos de edad de 35.0 a 49.9 y de 50.0 a 69.9, debe tomarse en general la primera prueba para ambos brazos, en el grupo de 14.0 a 19.9 años la segunda prueba y en la edad de 20.0 a 34.9 años el mejor resultado del brazo no dominante es la primera y del brazo dominante la segunda prueba.
\end{abstract}

Palabras claves: PRESIÓN DE MANO / FUERZA MÁXIMA / FUERZA EXPLOSIVA / RESISTENCIA DE CRITERIO / IMPULSO DE POTENCIA

Reacived: 26. 09. 2017

Accepted: 11. 12. 2017 


\title{
ПОУЗДАНОСТ МЕРЕЊА РАЗЛИЧИТИХ КОНТРАКТИЛНИХ ФУНКЦИЈА ПРЕГИБАЧА ПРСТИЈУ ШАКЕ КОД МУШКАРАЦА РАЗЛИЧИТОГ УЗРАСТА
}

\author{
Милан Р. Марковић ${ }^{1}$, Миливој Допсај ${ }^{1}$, Ненад Коропановски ${ }^{2}$, Немања Ћопић, \\ Марија Станковић ${ }^{4}$ \\ ${ }^{1}$ Универзитета у Београду, Факултет спорта и физичког васпитања, студент ДАС \\ ${ }^{2}$ Криминалистичко полицијска академија, Београд \\ ${ }^{3}$ Универзитет „Унион - Никола Тесла“, Факултет за спорт, Београд \\ ${ }^{4}$ Висока здравствена школа струковних студија у Београду
}

\begin{abstract}
Сажетак
Циљ истраживања је да се утврди поузданост тестирања различитих контрактилних функција шаке мушкараца, у зависности од моторичко-функционалне доминантности и узраста. Испитаник заузима седећи положај са опруженом или благо флексираном руком, постављеном у благо абдукциони положај. За потребе мерења употребљена је динамометријска сонда, са изометријским условима напрезања, фиксирана за специјалну конструкцију. Коришћен је софтвер “Isometrics” (вер. 3.1.1), а фреквенција одабира података реализована је на нивоу од $500 \mathrm{~Hz}$. Узорак је обухватио 269 испитаника мушког пола, узраста од 14.0 до 69.9 година. Резултати дескриптивне статистике су показали да се у односу на тестирани узорак за недоминантну руку вредности испољене максималне јачине $\left(\mathrm{F}_{\max }\right)$ налазе у распону од 462.8 до $529.0 \mathrm{~N}$, за експлозивну јачину $\left(\mathrm{RFD}_{\max }\right)$ у распону од 1621.6 до $1972.8 \mathrm{~N} / \mathrm{s}$ и за импулс мишићне јачине $\left(\mathrm{I}_{\operatorname{mp}} \mathrm{F}_{50 \% \max }\right)$ од 8203.9 до $15552.3 \mathrm{Ns}$, док су вредности $\mathrm{F}_{\max }$ за доминантну руку у распону од 478.1 до $566.2 \mathrm{~N}$, за RFD ${ }_{\max }^{50 \% \max }$ распону од 1742.6 до $2119.0 \mathrm{~N} / \mathrm{s}$ и за I $\mathrm{I}_{\operatorname{mp}} \mathrm{F}_{50 \% \max }$ од 9516.7 до 16845.1 Ns. Утврђено је да се поуздано могу мерити све три испитиване контрактилне карактеристике

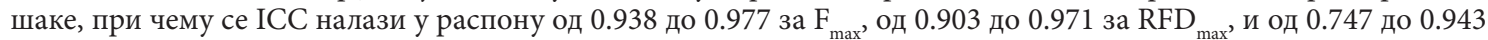

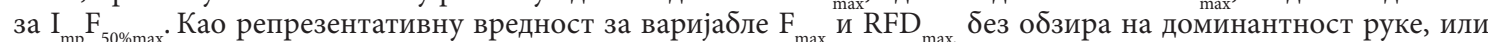
узрасну групу, треба узимати други покушај као бољи резултат. Док за варијаблу $\mathrm{I}_{\operatorname{mp}} \mathrm{F}_{50 \% \max }$, у узрасним групама од 35.0 до 49.9 и од 50.0 до 69.9 година, углавном треба узимати први тестирани покушај за обе руке, у групи од 14.0 до 19.9 година други тестирани покушај, а у узрасту од 20.0 до 34.9 година бољи резултат недоминантне руке је први, а доминантне други покушај.
\end{abstract}

КљУчНе речИ: СТИСАК ШАКЕ / МАКСИМАЛНА ЈАЧИНА / ЕКСПЛОЗИВНА ЈАЧИНА / КРИТЕРИЈУМСКА ИЗДРЖЉИВОСТ / ИМПУЛС СИЛЕ

\section{УВОД}

Сложена анатомска и функционална структура шаке је углавном усмерена на задатак хватања и држања као доминантне моторичке функције овог дела руке (Fernandes et al., 2014). Досадашња истраживања бавила су се различитим функционалним и моторичким карактеристикама шаке као сегмента руке, као и покушајем идентификације различитих биомеханичких аспеката испољавања карактеристика силе стиска шаке
(Bohannon, 2001; Nicolay and Walker, 2005; Допсај и cap., 2011; Fernandes et al., 2014). Утврђено је, да је доминантна рука за око $10 \%$ јача од недоминатне руке (Hager-Ros and Rosblad, 2002; Кљајић и сар., 2012), као и да мушкарци апсолутне максималне вредности силе достижу у четвртој деценији живота, а онда постепено „опадају” (Massy-Westropp et al., 2011). Потврђено је да максимална сила стиска шаке код деце и адолесцената може бити од користи за праћење биолошког развоја али и у функцији евалуације укупног мишићног развоја 
(Bohannon, 2001; Sartorio et al., 2002; Wind et al., 2010). Такође у области епидемиологије и геронтологије се користи у проучавању ефеката старења људске популације (Kerr et al., 2006), а значајан је показатељ и здравствених параметара код одраслих особа, као што је густина коштане масе или губитак протеина (Foo et al., 2007).

Анализирајући податке из доступне литературе може се доћи до закључка да су испитивани феномени контрактилности шаке већином односе на максималну силу (Müller et al., 2000; Dopsaj et al., 2007; Aadahl et al., 2011), веома мали број истраживања је реализовано у односу на експлозивну силу (Demura et al., 2003; Dopsaj et al., 2009a), као и у односу на карактеристике издржљивости у испољавању силе (Кљајић и сар., 2012). Уочљив је недостатак научних информација о метролошким карактеристикама различитих контрактилних способности мишића шаке добијених поменутим тестом „стисак шаке” у односу на узраст испитаника, поготову узимајући у обзир чињеницу да се током процеса одрастања (препубертетски, пубертетски и постпубертетски период) и током старења контрактилне способности мишића мењају (Aadahl et al., 2011).

Без обзира у којој се научној истраживачкој области примењује, чињеница је да је тест „стисак шаке" изузетно апликативан, једноставан и информативан, применом стандардизоване процедуре мерења. Потребно је дефинисати нове иновативне вредности како самог теста, тако и контрактилних карактеристика које се његовом применом мере, а све ради усавршавања технолошког поступка добијања валидних и поузданих информација које указују на физичко здравље и специјализовану мишићну функцију горњег дела тела, односно генералну индикацију о мишићним функцијама целог тела, популације од интереса. За дефинисања таквог експертског система неопходно је формирање велике базе података са референтним вредностима, где методолошки поступак формирања базе захтева иницијално дефинисање стања здраве популације оба пола у свим узрасним категоријама (Hager-Ros and Rosblad, 2002; Dopsaj et al., 2009b). Таква врста информација је од есенцијалног значаја у смислу критеријумских и нормативних вредности и користи се за потребе алгоритама одлучивања и прецизнијих тумачења резултата тестирања у смислу компарације како врхунских спортиста, тако и рекреативаца, али и остале популације, без обзира да ли се ради о нетренираним здравим, повређеним или болесним особама (Desrosiers et al., 1995; Müller et al., 2000; Bohannon, 2001; Kerr et al., 2006; Gallup et al., 2007; Dopsaj et al., 2007; Dopsaj et al., 2009a; Ivanovic et al., 2009; Dhara et al., 2009; Beloosesky et al., 2010; Carrasco et al., 2010).

Предмет овог истраживања је испитивање различитих контрактилних карактеристика шаке. Циљ истраживања је да се утврде поузданост и квантитативни дескриптивни показатељи, различитих контрактилних функција шаке код мушкараца различитог узраста, у односу на максималну и експлозивну јачину, и критеријумска издржљивост испољавања јачине у функцији моторичко-функционалне доминантности. С обзиром на већ испитиван простор поузданости контрактилних карактеристика како мишића доњих тако и горњих екстремитета са аспекта јачине и експлозивне јачине, где су резултати показали висок ниво поузданости (Blazevich et al., 2002; Demura et al.,2003; Ivanovic and Dopsaj, 2013; Jenkins et al., 2014), можемо очекивати сличне резултате у простору јачине и експлозивне јачине мишића шаке, али и претпоставити позитивне резултате у простору импулса мишићне јачине шаке.

\section{МЕТОД РАДА}

У овом истраживању, за потребе мерења контрактилних карактеристика мишићне силе коришћен је квантитативни приступ узорковања података и то методом динамометрије, тестирањем у изометријским условима напрезања (Допсај, 2010). Као основни метод мерења, коришћено је лабораторијско тестирање, применом стандардизованог теста - „стисак шаке“ (Dopsaj et al., 2007; Ivanovic et al., 2009; Допсај и сар., 2011). Као основни сазнајни метод примениће се аналитички и статистички метод, као и метод индукције, односно потпуне индукције.

\section{Узорак испитаника}

Узорком је обухваћено 269 испитаника мушког пола, узраста од 14.0 до 69.9 година, и то 59 испитаника узраста од 14.0 до 19.9 година - I група (ТВ $=181.9 \pm 6.1$ цМ, ТМ $=77.9 \pm 10.57$ кг, БМИ = 23.5 \pm 2.7 кг $\left./ \mathrm{M}^{2}\right), 123$ испитаника узраста од 20.0 до 34.9 година - II група (ТВ = 182.8 \pm 6.9 цм, ТМ $=86.1 \pm 14.4$ 
кг, БМИ $=25.7 \pm 3.4$ кг $\left./ \mathrm{M}^{2}\right), 47$ испитаника узраста од 35.0 до 49.9 година - III група (ТВ $=181.7 \pm 7.2$ цм, ТМ $=87.5 \pm 12.4$ кг, БМИ $\left.=26.5 \pm 3.41 \kappa г / \mathrm{M}^{2}\right)$ и 40 испитаника узраста од 50.0 до 69.9 година - IV група $(\mathrm{TB}=180.3 \pm 4.77$ цм, ТМ $=86.7 \pm 11.8$ кг, БМИ $\left.=26.6 \pm 3.16 \mathrm{\kappa г} / \mathrm{M}^{2}\right)$. Од укупног броја тестираних, 20 испитаника су пријавили леву руку као доминантну. Испитаници су изабрани методом случајног узорковања из опште и спортске популације. Сви су били упознати са условима тестирања и добровољно су учествовали у истраживању. Истраживање је реализовано у складу са условима Хелсиншке декларације, а уз одобрење и сагласност Етичке комисије Факултета спорта и физичког васпитања, Универзитета у Београду.

\section{Процедура мерења}

Испитаници су мерени применом стандардизоване процедуре, у седећем положају са опруженом или благо флексираном руком, постављеном у благо абдукциони положај (Допсај и сар., 2011; Кљајић и сар., 2012). Поступак мерења је био следећи - након самосталног загревања општег карактера у трајању од 3 минута (вежбе обликовања и растезања) сваком испитанику је објашњена процедура и начин тестирања. Након тога је извршено упознавање са тестом, тако што су испитаници реализовали по 3-4 иницијална покушаја стиска шаке са нижим интензитетима силе, односно пробали да реализују издржај сваком шаком наизменично у трајању до 10 секунди на произвољно изабраном нивоу силе у распону од 150 до $200 \mathrm{~N}$. После тога, сваки испитаник је извео по један пробни покушај максималног стиска шаке (недоминантном и доминантном) ради финалног упознавања са процедуром тестирања, али и у функцији завршне фазе специфичног загревања.

После одмора од 2 до 3 минута, испитаници су приступали мерењу по следећем протоколу прво су реализовали по два наизменична мерења максималне мишићне силе стиска шаке обе руке на припремни знак мериоца (испитаник је сам бирао којом руком започиње тестирање) ради одређивања нивоа од $100 \%$ дате контрактилне способности (максимално трајање контракције је до 2 секунде). Пауза између сваког покушаја тестирања једне руке је била најмање 1 минут.

Након тога, у наставку процедуре, после одмора од 2 до 3 минута, приступило се мерењу капацитета испољавања задате силе (издржљивост ис- пољавања изометријске мишићне силе), односно мерен је временски интервал у којем су испитаници могли да одржавају задати ниво силе од $50 \%$ од максималне, у складу са процедуром описаном раније (Marković et al., 2016). Задатак испитаника је био да гледајући у монитор на коме је приказан ниво силе одржавају дефинисани ниво силе у што дужем временском периоду све до вољног отказа. Време остварења задате силе регистровано је софтверски, а задатак мериоца је био да са испитаником гледа у монитор, и да коригује испитаника у односу на ниво реализације силе, као и да вербално мотивише испитаника да издржи задати моторички задатак у што дужем временском интервалу. У тренутку када испитаник више није могао да реализује дефинисан ниво силе, тј. када би пао на ниво испод 45\% од максимума, покушај је прекидан, а софтвер би забележио укупно време издржаја у задатом опсегу. Након одмора од најмање 5 минута исти тест је реализован и другом руком, а након паузе од најмање 10 минута, тест издржљивости је поновљен по истој процедури за обе руке.

Коришћена је динамометријска сонда која је фиксирана за конструкцију, специјално намењену за реализацију теста "Стисак шаке" (Marković et al., 2016), док је фреквенција одабира тј. узорковања података реализована на нивоу од $500 \mathrm{~Hz}$, а све то уз помоћ софтвера за анализу података "Isometrics" (вер. 3.1.1).

\section{Варијабле}

Испитивани простор је дефинисан у односу на три варијабле мишићне јачине шаке и то: са аспекта максималне јачине (изражено у N), максималне експлозивне јачине (изражено у N/s) и издржљивости у испољавању мишићне јачине, односно временски аспект испољавања датог процента јачине (изражено у - Ns).

За потребе овог истраживања су коришћене следеће варијабле:

1. Максимална мишићна јачина стиска шаке $\mathrm{F}_{\text {max }}$ и то: доминантне руке $\left(\mathrm{F}_{\max } \mathrm{D}\right)$ и недоминантне руке $\left(\mathrm{F}_{\max } \mathrm{ND}\right)$, кроз први (1) и други (2) покушај, изражена у њутнима (N);

2. Максимална вредност експлозивне јачине $\mathrm{RFD}_{\text {max, }}$, то: апсолутна вредност доминантне руке $\left(\mathrm{RFD}_{\max } \mathrm{D}\right)$ и недоминантне руке $\left(\mathrm{RFD}_{\max } \mathrm{ND}\right)$, кроз први (1) и други (2) покушај, изражена у њутнима у секунди (N/s), 
3. Импулс мишићне јачине, издржљивост стиска шаке остварен на нивоу од $50 \%$ од $\mathrm{F}_{\max }$ $\mathrm{I}_{\operatorname{mp}} \mathrm{F}_{50 \% \max }$ (израчунат као производ нивоа силе од $\mathrm{F}_{50 \% \max }$ и оствареног времена у издржају на поменутом нивоу силе) и то: доминантне руке $\left(\mathrm{I}_{\mathrm{mp}} \mathrm{F}_{50 \% \max } \mathrm{D}\right)$ и недоминантне руке $\left(\mathrm{I}_{\mathrm{mp}} \mathrm{F}_{50 \% \max } \mathrm{ND}\right)$, кроз први (1) и други (2) покушај, који је изражен у њутн-секундама (Ns).

\section{Статистичка обрада и анализа}

Сви резултати су прво анализирани применом основне дескриптивне статистичке методе где су израчунате: мере централне тенденције (аритметичка средина), мере дисперзије (стандардна девијација), и коефицијент варијације (Cv\%). Такође подаци су обрађени применом Студентовог т теста за зависне узорке. Након тога, реализована је линеарна регресиона анализа, као и анализа сличности парова варијабли, односно израчунат је параметар поузданости - Intraclass correlation coefficient (ICC) (Hair et al., 1998). Све статистичке анализе су извршене уз помоћ софтверског пакета „SPSS 19.0”, док је за ниво статистичке значајности коришћена вредност $\mathrm{p}<0.05$.

\section{РЕЗУЛТАТИ}

Просечне вредности мишићних карактеристика стиска шаке за недоминантну и доминантну руку целокупног узорака износиле су $501.8 \pm 97.1 \mathrm{~N}$ и $534.4 \pm 100.2 \mathrm{~N}$ за $\mathrm{F}_{\max }, 1837.0 \pm 446.2$ $\mathrm{N} / \mathrm{s}$ и $1984.8 \pm 494.7 \mathrm{~N} / \mathrm{s}$ за RFD $\max$ и $13537.4 \pm 5511.4$ Ns и $14458.6 \pm 6600.8$ Ns за I $\mathrm{I}_{\text {mp }} \mathrm{F}_{50 \% \max }$.

У Табели 1 приказани су резултати за оба покушаја мерених варијабли, доминантне и недоминантне руке, у функцији узрасних група испитаника. Уочено је да је највећа измерена $\mathrm{F}_{\max }$ стиска шаке недоминантне руке добијена код II узрасне групе и то за варијаблу $\mathrm{F}_{\max } \mathrm{ND} 2$, док је најмањи ниво силе измерен код I узрасне групе за варијаблу $\mathrm{F}_{\max } \mathrm{ND} 1 . \mathrm{У}$ односу на показатеље $\mathrm{F}_{\max }$ доминантне руке може се уочити да је највећа измерена сила стиска шаке утврђена код II узрасне групе и то за варијаблу $\mathrm{F}_{\max } \mathrm{D} 2$, док је најмања сила измерена код I узрасне групе за варијаблу $\mathrm{F}_{\max } \mathrm{D} 1$.

Код варијабле $\mathrm{RFD}_{\max }$, резултати су показали да је највећа експлозивна сила стиска шаке недоминантне руке измерена код II узрасне групе и то за варијаблу $\mathrm{RFD}_{\max } \mathrm{ND} 2$, док је најмањи ниво измерен код IV узрасне групе за варијаблу $\mathrm{RFD}_{\max } \mathrm{ND} 2$. У односу на добијене вредности $\mathrm{RFD}_{\text {max }}$ доминантне руке може се уочити да је највећи ниво експлозивне силе стиска шаке измерена у II узрасној групи и то за варијаблу $\mathrm{RFD}_{\text {max }} \mathrm{D} 2$, док су најмањи добијени резултати такође код IV узрасне групе за варијаблу RFD $\mathrm{max} \mathrm{D} 1$.

У односу на варијабле $\mathrm{I}_{\mathrm{mp}} \mathrm{F}_{50 \% \max }$ резултати су показали да је највећи импулс силе стиска шаке недоминантне руке на 50\% од испољеног максимума измерен код III узрасне групе и то за варијаблу $\mathrm{I}_{\mathrm{mp}} \mathrm{F}_{50 \% \max } \mathrm{ND} 1$, а најмањи импулс је измерен код I узрасне групе за варијаблу $\mathrm{I}_{\text {mp }} \mathrm{F}_{50 \% \max } \mathrm{ND}$. Највећи измерен импулс силе стиска шаке доминантне руке утврђен је исто код III узрасне групе и то за варијаблу $\mathrm{I}_{\operatorname{mp}} \mathrm{F}_{50 \% \max } \mathrm{D} 1$, а најмањи је измерен такође код I узрасне групе за варијаблу $\mathrm{I}_{\text {mp }} \mathrm{F}_{50 \% \max } \mathrm{D} 1$.

У односу на утврђене варијације резултата, као мере хомогености истих, резултати коефицијента варијације постигнутих нивоа максималне силе се налазе у распону од $16.8 \%$ до $20.7 \%$, док се за ниво експлозивности налазе у распону од $19.4 \%$ до 29.8\% што указује да измерени резултати $\mathrm{F}_{\max }$ и $\mathrm{RFD}_{\text {max }}$ припадају веома хомогеној групи испитаника, без обзира на узраст истих. Међутим у односу на варијацију измерених резултата код теста издржљивости у испољавању мишиће силе, вредност Cv\% се налази у распону од 30.6 за I $\mathrm{I}_{\mathrm{mp}} \mathrm{F}_{50 \% \max } \mathrm{D} 2$ код IV узрасне групе, до вредности $\mathrm{Cv} \% 58.0$ за I $\mathrm{I}_{\text {mp }} \mathrm{F}_{50 \% \max } \mathrm{ND} 1$ код I узрасне групе (Тaбела 1). Иако је утврђени ниво варијације изнад оптималне вредности од $30 \%$, односно припада категорији нехомогене групе, он се налази испод вредности од $60 \%$, што задовољава услове да се у наредној фази статистичке анализе користи параметријска статистика. 
Табела 1. Дескриптивна статистика мерених варијабли.

\begin{tabular}{|c|c|c|c|c|c|c|c|c|c|c|c|c|}
\hline Узрасне групе: & \multicolumn{3}{|c|}{ I } & \multicolumn{3}{|c|}{ II } & \multicolumn{3}{|c|}{ III } & \multicolumn{3}{|c|}{ IV } \\
\hline Варијабле: & Mean & $\begin{array}{l}\text { Std. } \\
\text { Dev. }\end{array}$ & Cv\% & Mean & $\begin{array}{l}\text { Std. } \\
\text { Dev. }\end{array}$ & $\mathrm{Cv} \%$ & Mean & Std. Dev. & Cv\% & Mean & Std. Dev. & $\mathrm{Cv} \%$ \\
\hline $\mathrm{F}_{\max } \mathrm{ND} 1(\mathrm{~N})$ & 462.8 & 87.6 & 18.9 & 519.6 & 98.0 & 18.9 & 507.9 & 105.3 & 20.7 & 481.2 & 87.1 & 18.1 \\
\hline $\mathrm{F}_{\max } \mathrm{ND} 2(\mathrm{~N})$ & 474.2 & 87.9 & 18.5 & 529.0 & 105.8 & 20.0 & 520.5 & 107.4 & 20.6 & 483.5 & 87.3 & 18.1 \\
\hline $\mathrm{RFD}_{\max } \mathrm{ND} 1(\mathrm{~N} / \mathrm{s})$ & 1813.2 & 493.0 & 27.2 & 1960.8 & 585.0 & 29.8 & 1822.5 & 428.6 & 23.5 & 1627.9 & 315.7 & 19.4 \\
\hline $\mathrm{RFD}_{\max } \mathrm{ND} 2(\mathrm{~N} / \mathrm{s})$ & 1859.7 & 441.0 & 23.7 & 1972.8 & 581.0 & 29.4 & 1893.7 & 446.2 & 23.6 & 1621.6 & 316.6 & 19.5 \\
\hline $\mathrm{I}_{\mathrm{mp}} \mathrm{F}_{50 \% \max } \mathrm{ND} 1(\mathrm{Ns})$ & 8203.9 & 4757.2 & 58.0 & 13970.3 & 6562.2 & 47.0 & 15552.3 & 7751.3 & 49.8 & 15317.7 & 6431.1 & 42.0 \\
\hline $\mathrm{I}_{\mathrm{mp}} \mathrm{F}_{50 \% \max } \mathrm{ND} 2(\mathrm{Ns})$ & 10555.6 & 4369.5 & 41.4 & 13685.9 & 5537.4 & 40.5 & 14770.2 & 7001.3 & 47.4 & 15137.8 & 5137.2 & 33.9 \\
\hline $\mathrm{F}_{\max } \mathrm{D} 1(\mathrm{~N})$ & 478.1 & 80.5 & 16.8 & 554.6 & 106.1 & 19.1 & 534.7 & 107.9 & 20.2 & 503.0 & 92.4 & 18.4 \\
\hline $\mathrm{F}_{\max } \mathrm{D} 2(\mathrm{~N})$ & 497.5 & 87.0 & 17.5 & 566.2 & 105.9 & 18.7 & 557.6 & 112.0 & 20.1 & 516.1 & 95.9 & 18.6 \\
\hline $\mathrm{RFD}_{\max } \mathrm{D} 1(\mathrm{~N} / \mathrm{s})$ & 1937.8 & 471.6 & 24.3 & 2087.7 & 565.5 & 27.1 & 1970.3 & 456.7 & 23.2 & 1742.6 & 385.3 & 22.1 \\
\hline $\mathrm{RFD}_{\max } \mathrm{D} 2(\mathrm{~N} / \mathrm{s})$ & 2011.0 & 487.4 & 24.2 & 2119.0 & 614.1 & 29.0 & 2015.4 & 470.0 & 23.3 & 1794.0 & 407.4 & 22.7 \\
\hline $\mathrm{I}_{\mathrm{mp}} \mathrm{F}_{50 \% \max } \mathrm{D} 1(\mathrm{Ns})$ & 9516.7 & 4940.1 & 51.9 & 15101.5 & 7109.4 & 47.1 & 16845.1 & 7717.4 & 45.8 & 16371.2 & 6636.4 & 40.5 \\
\hline $\mathrm{I}_{\mathrm{mp}} \mathrm{F}_{50 \% \max } \mathrm{D} 2(\mathrm{Ns})$ & 11685.4 & 4960.8 & 42.5 & 15351.7 & 6150.9 & 40.1 & 15845.5 & 6273.8 & 39.6 & 14798.1 & 4529.9 & 30.6 \\
\hline
\end{tabular}

У односу на резултате разлика средњих вредности испитиваних варијабли у функцији тестовних покушаја (Табела 2), утврђено је да разлика резултата првог и другог мерења код десет парова варијабли високо статистички значајна без обзира на узрасну групу испитаника, и то у распону од $\mathrm{t}=-2.015$ и $\mathrm{p}=0.049$ за $\mathrm{F}_{\max } \mathrm{ND}$ за III узрасну групу, до $\mathrm{t}=-4.115$ и $\mathrm{p}=0.000$ за $\mathrm{F}_{\max } \mathrm{D}$ за I узрасну групу. Код тринаест варијабли није утврђена статистичка значајност, тј. резултати се креће у распону од $\mathrm{t}=-1.919$ и $\mathrm{p}=0.061$ за $\mathrm{RFD}_{\max } \mathrm{ND}$ за III узрасну групу, до $\mathrm{t}=-0.050$ и $\mathrm{p}=0.961$ за I $\mathrm{I}_{\mathrm{mp}} \mathrm{F}_{50 \% \max } \mathrm{ND}$ за IV узрасну групу.

Табела 2. Анализа измерених разлика (

\begin{tabular}{|c|c|c|c|c|c|c|c|c|}
\hline Узрасне групе: & \multicolumn{2}{|c|}{ I } & \multicolumn{2}{|c|}{ II } & \multicolumn{2}{|c|}{ III } & \multicolumn{2}{|c|}{ IV } \\
\hline Вријабле: & $\mathrm{t}$ & $\mathrm{p}$ & $\mathrm{t}$ & $\mathrm{p}$ & $\mathrm{t}$ & $\mathrm{p}$ & $\mathrm{t}$ & $\mathrm{p}$ \\
\hline $\mathrm{F}_{\max } \mathrm{ND} 1(\mathrm{~N}) \& \mathrm{~F}_{\max } \mathrm{ND} 2(\mathrm{~N})$ & -3.172 & 0.002 & -2.266 & 0.025 & -2.015 & 0.049 & -0.553 & 0.583 \\
\hline $\mathrm{RFD}_{\max } \mathrm{ND} 1(\mathrm{~N} / \mathrm{s}) \& \mathrm{RFD}_{\max } \mathrm{ND} 2(\mathrm{~N} / \mathrm{s})$ & -2.374 & 0.021 & -0.482 & 0.631 & -1.919 & 0.061 & 0.305 & 0.762 \\
\hline $\mathrm{I}_{\mathrm{mp}} \mathrm{F}_{50 \% \max } \mathrm{ND} 1(\mathrm{Ns}) \& \mathrm{I}_{\mathrm{mp}} \mathrm{F}_{50 \% \max } \mathrm{ND} 2(\mathrm{Ns})$ & -1.848 & 0.074 & 0.300 & 0.765 & -0.857 & 0.402 & -0.050 & 0.961 \\
\hline $\mathrm{F}_{\max } \mathrm{D} 1(\mathrm{~N}) \& \mathrm{~F}_{\max } \mathrm{D} 2(\mathrm{~N})$ & -4.115 & 0.000 & -3.267 & 0.001 & -3.837 & 0.000 & -2.788 & 0.008 \\
\hline $\mathrm{RFD}_{\max } \mathrm{D} 1(\mathrm{~N} / \mathrm{s}) \& \mathrm{RFD}_{\max } \mathrm{D} 2(\mathrm{~N} / \mathrm{s})$ & -2.917 & 0.005 & -1.409 & 0.161 & -1.820 & 0.075 & -1.903 & 0.064 \\
\hline $\mathrm{I}_{\mathrm{mp}} \mathrm{F}_{50 \% \max } \mathrm{D} 1(\mathrm{Ns}) \& \mathrm{I}_{\mathrm{mp}} \mathrm{F}_{50 \% \max } \mathrm{D} 2(\mathrm{Ns})$ & -2.229 & 0.033 & -1.351 & 0.183 & -0.471 & 0.643 & 2.510 & 0.018 \\
\hline
\end{tabular}

У Табели 3 су приказани резултати поузданости у односу на испитиване варијабле и узрасне групе. Утврђено је да је ниво поузданости за сваку испитивану контрактилну карактеристику шаке у функцији узрасне групе високо статистички зна- чајан ( $\mathrm{p}=0.000$ за све испитиване парове варијабли). Вредност ICC, се налази за $\mathrm{F}_{\text {max }}$ у опсегу од 0.938 до 0.977 , за $\mathrm{RFD}_{\max }$ од 0.903 до 0.971 , и за $\mathrm{I}_{\mathrm{mp}} \mathrm{F}_{50 \% \max }$ од 0.747 до 0.943 . 
Табела 3. Резултати поузданости (Intraclass Correlation Coefficient)

\begin{tabular}{|c|c|c|c|c|c|c|c|c|}
\hline \multirow[b]{2}{*}{ Варијабле: } & \multirow{2}{*}{$\begin{array}{c}\text { Узрасне } \\
\text { групе: }\end{array}$} & \multirow{2}{*}{$\begin{array}{l}\text { Intraclass } \\
\text { Correlation } \\
\text { Coefficient }\end{array}$} & \multicolumn{2}{|c|}{ 95\% Conf. Inte. } & \multicolumn{4}{|c|}{ F Test with True Value 0} \\
\hline & & & $\begin{array}{l}\text { Lower } \\
\text { Bound }\end{array}$ & $\begin{array}{l}\text { Upper } \\
\text { Bound }\end{array}$ & Value & df1 & df 2 & $\mathrm{p}$ \\
\hline \multirow{4}{*}{$\begin{array}{c}\mathrm{F}_{\max } \mathrm{ND} 1(\mathrm{~N}) \\
\& \\
\mathrm{~F}_{\max } \mathrm{ND} 2(\mathrm{~N})\end{array}$} & $\mathrm{I}$ & 0.971 & 0.944 & 0.984 & 39.599 & 58 & 58 & 0.000 \\
\hline & II & 0.944 & 0.920 & 0.961 & 18.545 & 122 & 122 & 0.000 \\
\hline & III & 0.956 & 0.918 & 0.976 & 23.884 & 46 & 46 & 0.000 \\
\hline & IV & 0.977 & 0.957 & 0.988 & 43.581 & 39 & 39 & 0.000 \\
\hline \multirow{4}{*}{$\begin{array}{c}\mathrm{RFD}_{\max } \mathrm{ND} 1(\mathrm{~N} / \mathrm{s}) \\
\& \\
\mathrm{RFD}_{\max } \mathrm{ND} 2(\mathrm{~N} / \mathrm{s})\end{array}$} & I & 0.971 & 0.950 & 0.983 & 37.513 & 58 & 58 & 0.000 \\
\hline & II & 0.941 & 0.915 & 0.959 & 16.798 & 122 & 122 & 0.000 \\
\hline & III & 0.903 & 0.824 & 0.946 & 10.854 & 46 & 46 & 0.000 \\
\hline & IV & 0.956 & 0.917 & 0.977 & 22.411 & 39 & 39 & 0.000 \\
\hline \multirow{4}{*}{$\begin{array}{c}\mathrm{I}_{\mathrm{mp}} \mathrm{F}_{50 \% \max } \mathrm{ND} 1(\mathrm{Ns}) \\
\& \\
\mathrm{I}_{\mathrm{mp}} \mathrm{F}_{50 \% \max } \mathrm{ND} 2(\mathrm{Ns})\end{array}$} & $\mathrm{I}$ & 0.761 & 0.509 & 0.884 & 4.430 & 30 & 30 & 0.000 \\
\hline & II & 0.875 & 0.780 & 0.929 & 7.892 & 49 & 49 & 0.000 \\
\hline & III & 0.943 & 0.858 & 0.977 & 17.313 & 19 & 19 & 0.000 \\
\hline & IV & 0.771 & 0.514 & 0.891 & 4.251 & 29 & 29 & 0.000 \\
\hline \multirow{4}{*}{$\begin{array}{c}\mathrm{F}_{\max } \mathrm{D} 1(\mathrm{~N}) \\
\& \\
\mathrm{~F}_{\max } \mathrm{D} 2(\mathrm{~N})\end{array}$} & I & 0.938 & 0.858 & 0.969 & 20.340 & 58 & 58 & 0.000 \\
\hline & II & 0.961 & 0.941 & 0.974 & 27.667 & 122 & 122 & 0.000 \\
\hline & III & 0.954 & 0.884 & 0.978 & 27.937 & 46 & 46 & 0.000 \\
\hline & IV & 0.970 & 0.935 & 0.985 & 38.865 & 39 & 39 & 0.000 \\
\hline \multirow{4}{*}{$\begin{aligned} \mathrm{RFD}_{\max } \mathrm{D} 1(\mathrm{~N} / \mathrm{s}) \\
\& \\
\mathrm{RFD}_{\max } \mathrm{D} 2(\mathrm{~N} / \mathrm{s})\end{aligned}$} & I & 0.953 & 0.912 & 0.973 & 23.732 & 58 & 58 & 0.000 \\
\hline & II & 0.954 & 0.934 & 0.968 & 21.963 & 122 & 122 & 0.000 \\
\hline & III & 0.964 & 0.934 & 0.980 & 28.735 & 46 & 46 & 0.000 \\
\hline & IV & 0.948 & 0.901 & 0.973 & 20.566 & 39 & 39 & 0.000 \\
\hline \multirow{4}{*}{$\begin{array}{l}\mathrm{I}_{\operatorname{mp}} \mathrm{F}_{50 \% \max } \mathrm{D} 1(\mathrm{Ns}) \\
\stackrel{\mathrm{I}}{\mathrm{I}_{\mathrm{mp}}} \mathrm{F}_{50 \% \max } \mathrm{D} 2(\mathrm{Ns})\end{array}$} & I & 0.769 & 0.515 & 0.889 & 4.753 & 30 & 30 & 0.000 \\
\hline & II & 0.747 & 0.557 & 0.856 & 4.002 & 49 & 49 & 0.000 \\
\hline & III & 0.894 & 0.732 & 0.958 & 9.104 & 19 & 19 & 0.000 \\
\hline & IV & 0.836 & 0.632 & 0.925 & 7.017 & 29 & 29 & 0.000 \\
\hline
\end{tabular}

Линеарном регресионом анализом (Табела 4; Графикони 1 до 6), дефинисани су регресиони модели поузданости тестирања, тј. модели линеарних регресионих једначина свих тестираних варијабли за све узрасте. На графиконима су приказани резултати линеарне регресионе анализа у односу на тестирања (Тест 1 и 2) за варијаблу $\mathrm{F}_{\max }$ у функцији недоминантне (Графикон 1 ) и доминантне руке (Графикон 2), за варијаблу RFD ${ }_{\max }$ у функцији недоминантне (Графикон 3) и доминантне руке (Графикон 4), и за варијаблу $\mathrm{I}_{\operatorname{mp}} \mathrm{F}_{50 \% \max }$

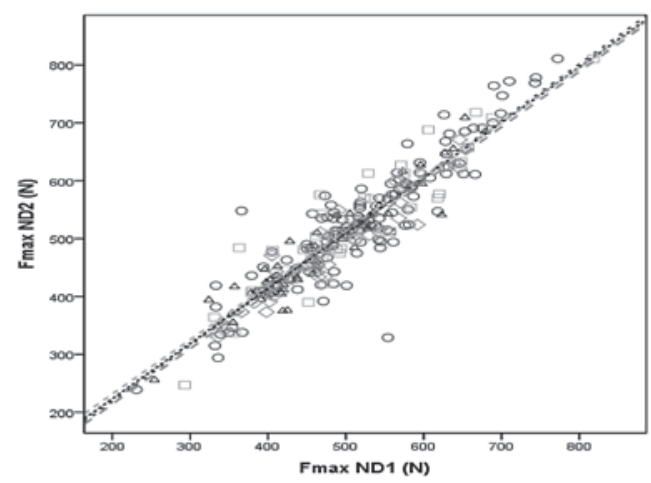

Графикон $1^{*}$ у функцији недоминантне (Графикон 5) и доминантне руке (Графикон 6). За варијаблу $\mathrm{F}_{\text {max }}$ опсег коефицијента детерминације $\left(\mathrm{R}^{2}\right)$ за доминантну руку је $0.826-0.903$, а за недоминантну руку 0.811-0.912. Код друге варијабле $\mathrm{RFD}_{\text {max }}$ се налази у опсегу 0.826-0.871 за доминантну и 0.692-0.910 за недоминантну, а варијабла $\mathrm{I}_{\operatorname{mp}} \mathrm{F}_{50 \% \max }$ има опсег коефицијента $\mathrm{R}^{2}$ за доминантну $0.360-0.674$, док 0.401-0.808 за недоминантну руку (Табела 4). Сви регресиони модели поузданости су показали висок ниво значајности на нивоу од $\mathrm{p}=0.000$.

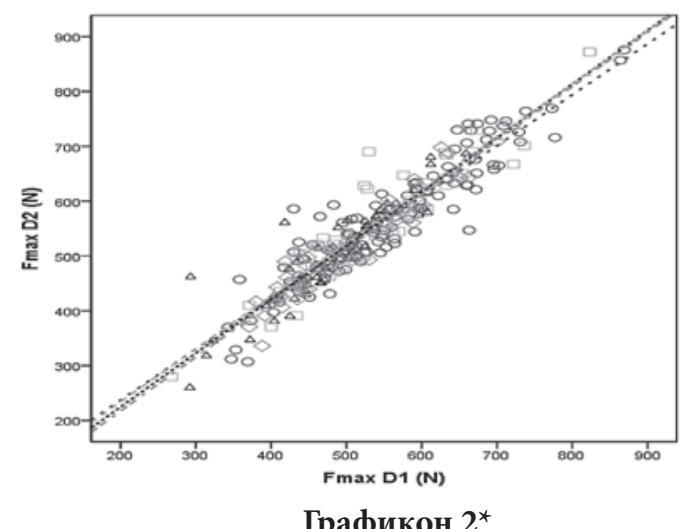

Графикон $2^{*}$

*Линеарна регресија $\mathrm{F}_{\text {max }}$ I и II покушаја недоминантне (графикон 1) и доминантне руке (графикон 2) 


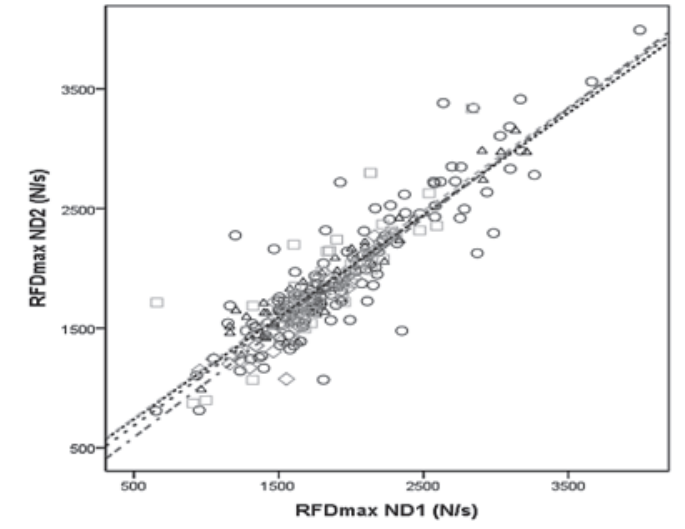

Графикон $3^{*}$

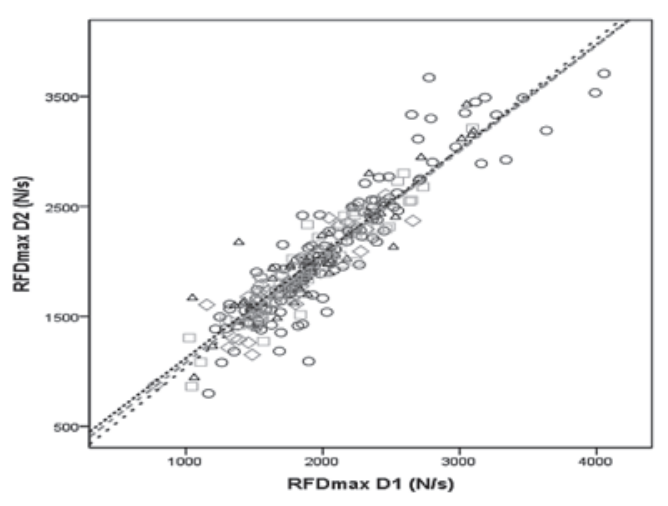

Графикон $4^{*}$

*Линеарна регресија RFD ${ }_{\text {max }}$ I и II покушаја недоминантне (Грфикон 1) и доминантне руке (Графикон 2)

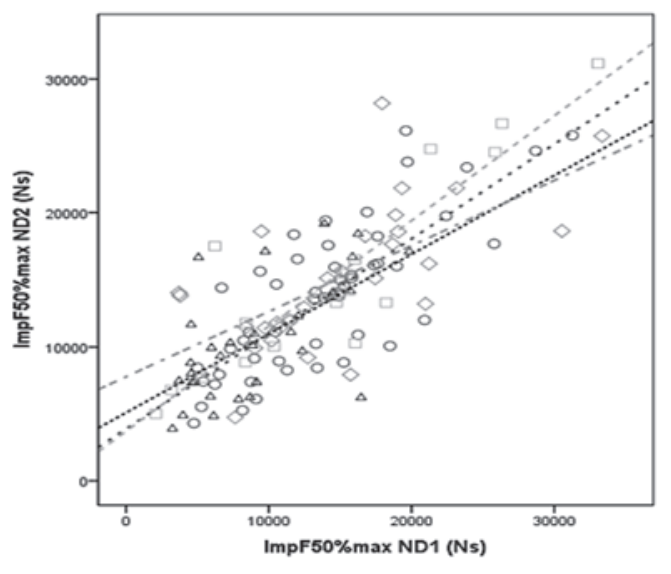

Графикон $5^{\star}$

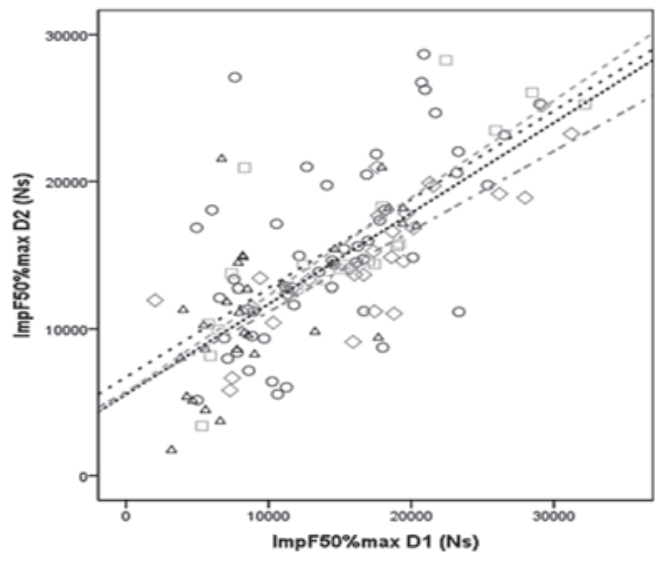

Графикон $6^{*}$

*Линеарна регресија I $\mathrm{mp}_{50 \% \max }$ I и II покушаја недоминантне (Графикон 5) и доминантне руке (Графикон )

Табела 4. Резултати дефинисаних модела линеарних регресионих једначина

\begin{tabular}{|c|c|c|c|c|}
\hline \multirow{2}{*}{ Варијабле: } & \multicolumn{4}{|c|}{ Узрасне групе: } \\
\hline & 1 & II & III & IV \\
\hline \multirow{2}{*}{$\mathrm{F}_{\max } \mathrm{ND} 1(\mathrm{~N}) \& \mathrm{~F}_{\max } \mathrm{ND2}(\mathrm{N})$} & $y=0.955 \bullet x+32.237$ & $y=0.972 \cdot x+24.147$ & $y=0.938 \cdot x+43.905$ & $y=0.958 \cdot x+22.537$ \\
\hline & $R^{2}=0.904$ & $\mathrm{R}^{2}=0.811$ & $R^{2}=0.846$ & $R^{2}=0.912$ \\
\hline \multirow{2}{*}{$\begin{array}{l}\mathrm{RFD}_{\max } \mathrm{ND} 1(\mathrm{~N} / \mathrm{s}) \& \\
\mathrm{RFD}_{\max } \mathrm{ND} 2(\mathrm{~N} / \mathrm{s})\end{array}$} & $y=0.853 \cdot x+312.324$ & $y=0.882 \cdot x+244.349$ & $y=0.866 \bullet x+315.077$ & $y=0.917 \cdot x+128.561$ \\
\hline & $R^{2}=0.910$ & $R^{2}=0.788$ & $R^{2}=0.692$ & $R^{2}=0.836$ \\
\hline \multirow{2}{*}{$\begin{array}{l}\mathrm{I}_{m_{\mathrm{p}}} \mathrm{F}_{50 \% \text { max }} \mathrm{ND} 1(\mathrm{NS}) \& \\
\mathrm{I}_{\operatorname{mp}} \mathrm{F}_{50 \% \text { max }} \mathrm{ND} 2(\mathrm{NS})\end{array}$} & $y=0.589 \cdot x+5095.834$ & $y=0.708 \cdot x+3881.749$ & $y=0.785 \bullet x+3710.923$ & $y=0.488 \bullet x+7780.499$ \\
\hline & $R^{2}=0.401$ & $R^{2}=0.606$ & $R^{2}=0.808$ & $R^{2}=0.413$ \\
\hline \multirow{2}{*}{$\mathrm{F}_{\max } \mathrm{D} 1(\mathrm{~N}) \& \mathrm{~F}_{\max } \mathrm{D} 2(\mathrm{~N})$} & $y=0.981 \cdot x+28.355$ & $y=0.928 \cdot x+51.338$ & $y=0.967 \cdot x+40.519$ & $y=0.986 \cdot x+20.174$ \\
\hline & $R^{2}=0.826$ & $R^{2}=0.865$ & $R^{2}=0.868$ & $R^{2}=0.903$ \\
\hline \multirow{2}{*}{$\begin{array}{l}\mathrm{RFD}_{\text {max }} \mathrm{D} 1(\mathrm{~N} / \mathrm{s}) \& \\
\mathrm{RFD}_{\max } \mathrm{D} 2(\mathrm{~N} / \mathrm{s})\end{array}$} & $y=0.950 \bullet x+169.398$ & $y=0.995 \cdot x+42.115$ & $y=0.960 \cdot x+123.024$ & $y=0.961 \cdot x+119.489$ \\
\hline & $R^{2}=0.846$ & $R^{2}=0.839$ & $R^{2}=0.871$ & $R^{2}=0.826$ \\
\hline \multirow{2}{*}{$\begin{array}{l}\mathrm{I}_{m p} F_{50 \% \max } \mathrm{D} 1(\mathrm{Ns}) \& \\
\mathrm{I}_{\mathrm{mp}} \mathrm{F}_{50 \% \max } \mathrm{D} 2(\mathrm{Ns})\end{array}$} & $y=0.615 \cdot x+5548.499$ & $y=0.603 \cdot x+6729.400$ & $y=0.661 \bullet x+5679.263$ & $y=0.545 \bullet x+5721.218$ \\
\hline & $R^{2}=0.427$ & $R^{2}=0.360$ & $R^{2}=0.674$ & $R^{2}=0.657$ \\
\hline
\end{tabular}

*Легенда: Појединачне позиције резултата по узрасту: $\Delta$ - узрасна група од 14.0 до 19.9 - I група; ○ - узрасна група од 20.0 до 34.9 - II група; $\square$ - узрасна група од 35.0 до 49.9 - III група; $\diamond$ - узрасна група од 50.0 до 69.9 година - IV група, а у истим бојама су приказане и регресионе праве, тј. плавом I узрасна група; црвеном II узрасна група; жутом III узрасна група; зеленом IV узрасна група. 


\section{ДИСКУСИЈА}

Испитивања контрактилних способности мишића шаке су од великог значаја како у предвиђању функционалних ограничења и дијагностици неуралних поремећаја тако имају и значајну улогу у процени општег нивоа развијености контрактилних физичких атрибута код професионалних спортиста и рекреативаца (Desrosiers et al., 1995; Rantanen et al., 1998; Bohannon, 2001; Wind et al., 2010; Koley et al., 2011). Истраживања овог типа представљају перманентно актуелно поље интересовања научно-истраживачког рада због повећања фундуса знања, али и ради усавршавања процедура мерења и праћења, како у дијагностичке, тако и у терапијске и професионалне сврхе.

На основу резултата овог истраживања уврђена је и статистички значајна разлика средњих вредности код варијабли $\mathrm{F}_{\max }$ првог и другог покушаја доминантне руке свих узрасних категорија, али и код недоминантне руке у прве три тестиране групе (I, II, III узрасна група) (Табела 2). И остале статистичке анализе, којима је испитивана поузданост мерења, су показале изузетно висок ниво испољавања максималне силе $\left(\mathrm{F}_{\max }\right)$ стиска шаке код свих тестираних узрасних група и то на нивоу ICC од 0.944 до 0.977 за недоминантну руку, односно од 0.938 до 0.970 ICС за доминантну руку, респективно (Табела 3). Добијени резултати су у сагласности се претходно утврђеним стандардима у односу на поузданост стандардних тестова јачине стиска шаке од 0.961 за десну руку до 0.950 за леву руку (Hamilton et al., 1994), односно у складу са високом поузадношћу стандардних тестова јачине и код осталих мишићних група у опсегу од ICC 0.97-1.00 за изометријски чучањ и гурање ногама из стојеће позиције (Blazevich et al., 2002), као и за стандардни потисак ногама, Cronbach's Alpha на нивоу од 0.989 (Ivanovic and Dopsaj, 2013). Peзултати су показали да је примена изометријског тестирања, а у односу на мерење максималне силе код теста стиска шаке, поуздан извор информација који је у функцији различитог узраста испитаника мушког пола. Мора се напоменути да се због утврђене статистички значајне разлике другог мерења у односу на прво, као финални резултат треба узети други покушај, односно резултат јачег покушаја.

У случају друге тестиране варијабле, којом је мерен максимални ниво експлозивне јачине тj. силе - $\mathrm{RFD}_{\text {max, }}$ статистичка значајна разлика између тестовних покушаја је утврђена само у I узрасној групи и у случају доминантне и недоминантне руке (Табела 2). Ово се може објаснити одсуством претходног искуства извођења сличних напрезања и њихове иницијалне моторне неприлагођености на задатак у првом покушају, односно повећане акутне неуро-моторне адаптираности за други покушај. Даље статистичке анализе су показале изузетно висок ниво поузданости испољавања дате контрактилне карактеристике $\mathrm{RFD}_{\max }$ стиска шаке код свих тестираних узрасних група и то на нивоу ICC од 0.903 до 0.971 за недоминантну руку, односно од 0.948 до 0.964 ICC за доминантну руку (Табела 3). Као и у случају $\mathrm{F}_{\max }$ и ови резултати су у сагласности са претходно утврђеним стандардима у односу на поузданост методе за тестирање испољавања експлозивне јачине стиска шаке где је ICC на нивоу 0.870-0.930 (Demura et al., 2003; Jenkins et al., 2014), односно у складу са високом поузданошћу стандардних тестова јачине и код осталих мишићних група на нивоу од 0.808-0.945 Cronbach's Alpha за стандардни потисак ногама (Ivanovic and Dopsaj, 2013). На основу досадашњих истраживања, али и добијених резултата овог истраживања, показало се да је примена изометријског тестирања, а у односу на мерење максималне експлозивне јачине код теста „стиска шаке“ поуздан и у функцији различитог узраста испитаника код мушкараца. Треба напоменути да је статистички значајна разлика другог мерења у односу на прво, утврђена само у I узрасној групи за обе руке. Без обзира на то, апсолутне разлике у просечним оствареним резултатима у корист другог покушаја могу се увидети на основу резултата дескриптивне статистике, у свим узрасним категоријама, осим у IV узрасној групи недоминантном руком, где је први тестовни покушај био бољи (Табела 1). На основу изнетог може се препоручити да као финални резултат треба узети експлозивнији покушај, односно резултат другог покушаја.

Док у трећој тестираној варијабли, којом је мерен импулс одржавања силе на 50\% од максималне - $\mathrm{I}_{\mathrm{mp}} \mathrm{F}_{50 \% \max }$ значајна разлика између првог и другог покушаја тестирања јавља се у I узрасној групи, али и у IV узрасној групи и то само за доминантну руку (Табела 2). Важан фактор овог теста је коришћење сензорних информација, тј. визуелног праћења одржања задатог нивоа силе 
на 50\% од максимума, и њихове усклађености (моторне контроле) са карактеристикама мишићног рада (издржљивошћу мишића), где у спорним узрасним категоријама долази до процеса убрзаног развоја или деградације исте, у чему вероватно лежи узрок добијених резултата (Nicolay and Walker, 2005). На основу резултата утврђен је статистички значајан ниво поузданости испољавања $\mathrm{I}_{\text {mp }} \mathrm{F}_{50 \% \max }$ стиска шаке код свих тестираних узрасних група и то на нивоу ICC од 0.761 до 0.943 за недоминантну руку, тј. од 0.747 до 0.894 ICC за доминантну руку (Табела 3). Функционална способност мишића за испољавање задатог нивоа силе као мера издржљивости, изражена као импулс силе није много истраживан феномен у спорту (Nicolay and Walker, 2005; Кљајић и сар., 2012). И поред статистички значајне разлике између тестовних покушаја $\mathrm{I}_{\mathrm{mp}} \mathrm{F}_{50 \% \max }$ само у I и IV узрасној групи доминантне руке (Табела 2), разлике у просечним оствареним резултатима могу се увидети на основу резултата дескриптивне статистике (Табела 1). На основу тога може се препоручити да се као финални резултат узима вредност која представља већу издржљивост, али да у III и IV узрасној групи први тестовни покушај углавном представља бољи резултат за обе руке, док у I узрасној групи то представља други покушај, a y II узрасној групи репрезент бољег резултата недоминантне руке је први, а доминантне други покушај.

Утврђен је висок ниво значајности регресионих модела поузданости тестирања свих варијабли за све узрасте. Можемо се рећи да је велики део варијансе другог мерења објашњен кроз прво и то за $\mathrm{F}_{\max }$ y распону од $81 \%$ до $91 \%$, за $\mathrm{RFD}_{\text {max }} \mathrm{y}$ распону од $69 \%$ до $91 \%$ и за I $\mathrm{I}_{\mathrm{mp}} \mathrm{F}_{50 \% \max }$ y распону од $36 \%$ до $80 \%$. Притом уочава се да су остварени резултати, линеарном регресионом анализом за $\mathrm{F}_{\max }$ и $\mathrm{RFD}_{\text {max }}$ нешто нижи него вредности досадашњих истраживања које се крећу у опсегу 96 \% до 99 \% за обе варијабле (Giampaoli et al., 1999; Dopsaj et al.,2009b). Регресиони модели поузданости $\mathrm{I}_{\mathrm{mp}} \mathrm{F}_{50 \% \max }$ нису уочени као предмет досадашњег интересовања, па изостаје могућност поређења. На овај начин је обезбеђена могућност предикције оптималног резултата мерених контрактилних карактеристика шаке као и позиционирање актуелног испитаника у функцији дефинисаних популационих стандарда.

\section{ЗАКЉУЧАК}

Стисак шаке представља важан извор података и методу којом је могуће дијагностификовати ниво функционално-радне способности испитиваних контрактилних својстава шаке као основног манипулативног сегмента руке, а која указује и на опште стање мишићне функције организма у целини.

У складу са циљем истраживања, дефинисани су квантитативни дескриптивни показатељи који могу послужити и код упоређивања и утврђивања нивоа развијености наведених способности код особа различите утренираности, различитог функционалног и здравственог стања, као и код особа са различитим степенима моторичких или неких других поремећаја и тиме остварити широку применљивост са многих сазнајних и практичних аспеката. Притом, може се тврдити да се са тестом „стисак шаке“ могу поуздано мерити све три испитиване контрактилне карактеристике шаке - максимална и експлозивна јачина, као и издржљивост испољавања јачине код мушкараца узраста од 14.0 до 69.9 година старости.

Наравно као финални показатељ контрактилних карактеристика мишића, узима се вредност која представља бољи резултат. Одсуством претходног искуства извођења сличних напрезања и њихове иницијалне моторне неприлагођености на задатак, утврђено је, да се за репрезентативну вредност варијабле $\mathrm{F}_{\max }$ и $\mathrm{RFD}_{\max }$ узима други покушај као показатељ бољег резултата, без обзира на доминантност руке или узрасну групу. За варијаблу $\mathrm{I}_{\mathrm{mp}} \mathrm{F}_{50 \% \max }$, након 35 . године углавном треба узимати први тестовни покушај за обе руке, док у најмлађој тестираној групи други тестовни покушај. У узрасту од 20.0 до 34.9 година показатељ бољег резултата недоминантне руке је први, а доминантне други покушај.

\section{НАПОМЕНА}

Рад је део пројекта "Ефекти примене физичке активности на локомоторни, метаболички, психосоцијални и образовни статус становништва Републике Србије", број III47015, који финансира Министарство просвете, науке и технолошког развоја Републике Србије - циклус научних пројеката 2011 - 2017. 


\section{ЛИТЕРАТУРА}

1. Aadahl, M., Beyer, N., Linneberg, A., Thuesen, B.H. \& Jørgensen, T. (2011). Grip strength and lower limb extension power in 19-71 years old Danish men and women: the Health 2006 study. BMJ Open, doi:10.1136/bmjopen-2011-000192.

2. Beloosesky, Y., Weiss, A., Manasian, M. \& Salai, M. (2010). Handgrip strength of the elderly after hip fracture repair correlates with functional outcome. Disability and Rehabilitation, 32(5), 367-673.

3. Blazevich, A., Gill, N. \& Newton, R. (2002). Reliability and validity of two isometic squat tests. Journal of Strength and Conditioning Research, 16(2), 298-304.

4. Bohannon, R.W. (2001). Dynamometer measurements of hand grip strength predict multiple outcomes. Percept Motor Skills, 93, 323-328.

5. Carrasco, L., Pradas, F., Floría, P., Martínez, A., Herrero, R. \& Juraldo, J. A. G. (2010). Grip strength in young Top-level table tennis players. International Journal of Table Tennis Sciences, 6, 64-66.

6. Demura, S., Yamaji, S., Nagasawa, Y., Sato, S., Minami, M. \& Yoshimura, Y. (2003). Reliability and gender differences of static explosive grip parameters based on force-time curves. The Journal of Sports Medicine and Physical Fitness, 43, 28-35.

7. Desrosiers, J., Bravo, G., Hebert, R. \& Dutil, E. (1995). Normative data for grip strength of elderly men and women. The American Journal of Occupational Therapy, 49(7), 637-644.

8. Dhara, P.C., De, S., Pal, A., Sengupta, P. \& Roy, S. (2009). Assessment of hand grip strength of orthopedically challenged persons affected with upper extremity. Journal of Life Sciences,1(2), 121-127.

9. Допсај, М. (2010). Карактеристике Ф-т криве: Аналитички и дијагностички значај у спорту. У Р. Станковић (Ед.), Зборник раgова са XIV Међунаровни научни скуй - ФИС КОМУНИ-

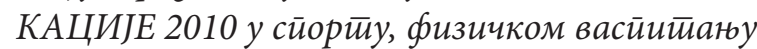
и рекреацији (п. 47-69). Ниш: Факултет спорта и физичког васпитања.

10. Dopsaj, M., Ivanović, J., Blagojević, M., Koropanovski, N., Vučković, G., Janković, R. \& Miljuš, D. (2009a). Basic and specific characteristics of the hand grip explosive force and time parame- ters in different strength trained population. Brazilian Journal of Biomotricity, 3(2), 177-193.

11. Dopsaj, M., Ivanović, J., Blagojević, M. \& Vučković, G. (2009b). Descriptive, functional and sexual dimorphism of explosive isometric hand grip force in healthy university students in Serbia. FACTA UNIVERSITATIS: Series Physical Education and Sport, 7(2), 125-139.

12. Допсај, М., Кљајић, Д., Еминовић, Ф., Коропановски, М., Димитријевић, Р. и Стојковић, И. (2011). Моделни показатељи карактеристика мишићне силе код младих и здравих особа при моторичком задатку стисак шаке: пилот истраживање. Специјална едукација и рехабилитација, 10(1), 15-36.

13. Dopsaj, M., Koropanovski, N., Vučković, G., Blagojević, M., Marinković, B. \& Miljuš, D. (2007). Maximal isometric hand grip force in well-trained university students in Serbia: Descriptive, functional and sexual dimorphic model. Serbian Journal of Sports Sciences, 1(4), 138-147.

14. Fernandes, A.A., Natali, A.J., Vieira, B.C., Neves do Valle, M.A.A., Moreira, D.G., Massy-Westropp, N. \& Marins, B. (2014). The relationship between hand grip strength and anthropometric parameters in men. Archivos de Medicina del Deporte, 31(3), 160- 164.

15. Foo, L.H., Zhang, Q., Zhu, K., Ma, G., Greenfield, H. \& Fraser, D.R. (2007). Influence of body composition, muscle strength, diet and physical activity on total body and forearm mass in Chinese adolescent girls. The British Journal of Nutrition, 98(6), 1281-1287.

16. Gallupa, A.C., White, D.D. \& Gallup, G.G. (2007). Handgrip strength predicts sexual behavior, body morphology, and aggression in male college students. Evolution and Human Behavior, 28, 423-429.

17. Giampaoli, S., Ferrucci, L., Cecchi, F., Lo Noce, C., Poce, A., Dima, F., Santaquilani, A., Vescio, M.F. \& Menotti, A. (1999). Hand-grip strength predicts incident disability in non-disabled older men. Age and Ageing, 28, 283-288.

18. Hager-Ros, C. \& Rosblad, B. (2002). Norms for grip strength in children aged 4-16 years. Acta Paedriatrica, 91(6), 617-625. 
19. Hair, J., Anderson, R., Tatham, R. \& Black, W. (1998). Multivariate Data Analysis(Fifth Ed.). Prentice - Hall, Inc., USA.

20. Hamilton, A., Balnave, R. \& Adams, R. (1994). Grip srrenght testing reliability. Journal of Hand Therapy, 7, 163-170.

21. Ivanovic, J., Koropanovski, N., Vuckovic, G., Jankovic, R., Miljus, D., Marinkovic, B. \& Dopsaj, M. (2009). Functional dimorphism and characteristics considering maximal hand grip force in top level athletes in the Republic of Serbia. Gazzetta Medica Italiana Archivio per le Scienze Mediche, 168(5), 297-310.

22. Ivanovic, J. \& Dopsaj, M. (2013). Reliability of force-time curve characteristics during maximal isometric leg press in differently trained high-level athletes. Measurement, 46, 2146-2154.

23. Kadir, E., Harmaa, A., Cetinb, A., Elmalia, N., Yologluc, S., Bostana, H. \& Sakaryaa, B. (2005). An investigation of hand dominance, average versus maximum grip strength, body mass index and ages as determinants for hand evaluation. Isokinetics and Exercise Science, 13, 223-227.

24. Kattel, B.P., Fredericks, T.K., Fernandez, J.E. \& Lee, D.C. (1996). The effect of upper-extremity posture on maximum grip strength. International Journal of Industrial Ergonomics, 18(5-6), 423429.

25. Kerr, A., Syddall, H.E., Cooper, C., Turner, G.F., Briggs, R.S. \& Sayer, A.A. (2006). Does admission grip strength predict length of stay in hospitalized older patients?. Age and Ageing, 35(1), 82-84.

26. Кљајић, Д., Еминовић, Ф., Трговчевић, С., Димитријевић, Р. и Допсај, М. (2012). Функционални однос недоминантне и доминантне руке при моторичком задатку - издржљивост у сили стиска шаке. Сиещијална еgукащија и рехабилитиација, 11(1), 67-85.

27. Koley, S., Singh, S. \& Kaur, S. (2011). A study of arm anthropometric profile in Indian interuniversity basketball players. Serbian Journal of Sports Sciences, 5(1), 35-40.
28. Marković, M., Dopsaj, M. \& Kasum, G. (2016). Differences between contractile characteristics of wrestler's hand and control group of young, moderately active people.U S. Pantelic (Ed.), Zbornik radova sa XIX Scientific Conference „FIS COMMUNICATIONS 2016" in physical education, sport and recreation(str. 44-52). Niš:Faculty of sport and physical education.

29. Massy-Westropp, N., Gill, T., Taylor, A., Bohannon, R. \& Hill, C. (2011). Hand grip strength: age and gender stratified normative data in a population-based study. BMC Research Notes, 4, 127.

30. Müller, E., Benko, U., Raschner, C. \& Schwameder, H. (2000). Specific fitness training and testing in competitive sports. Medicine and Science in Sports and Exercise, 32(1), 216-220.

31. Nicolay, C.W. \& Walker, A.L. (2005). Grip strength and endurance: Influences of anthropometric variation, hand dominance, and gender. International Journal of Industrial Ergonomics, $35,605-618$.

32. Jenkins, N., Buckner, S., Bergstrom, H., Cochrane, K., Goldsmith, J., House, T., Johnson, G., Schmidt, R. \& Cramer, J. (2014). Reliability and relationships among handgrip strength, leg extensor strength and power, and balance in older men. Experimental Gerontology, 58, 47-50.

33. Rantanen, T., Masaki, K., Foley, D., Izmirlian, G., White, L. \& Guralnik, J. M. (1998). Grip strength changes over $27 \mathrm{yr}$ in Japanese-American men. Journal of Applied Physiology, 85(6), 2047-2053.

34. Sartorio, A., Lafortuna, C.L., Pogliaghi, S. \& Trecate, L. (2002). The impact of gender, body dimension and body composition on hand-grip strength in healthy children. Journal of Endocrinological Investigation, 25(5), 431-435.

35. Wind, A., Takken, T., Helders, P. \& Engelbert, R. (2010). Is grip strength a predictor for total muscle strength in healthy children, adolescents, and young adults?. European Journal of Pediatrics, 169, 281-287. 


\title{
FIABILIDAD DE MEDICIÓN DE DISTINTAS FUNCIONES CONTRÁCTILES DEL FLEXOR DE LOS DEDOS DE MANO EN HOMBRES DE DISTINTA EDAD
}

\begin{abstract}
Resumen
El objetivo de la investigación es establecer la fiabilidad de las pruebas de distintas funciones contráctiles de la mano de varón en dependencia de la dominación motriz-funcional y de la edad. La persona examinada toma la posición sedentaria con el brazo extendido o suavemente flexible, puesto en una ligera posición de abducción. Para las necesidades de medición se ha utilizado una sonda dinamométrica con las condiciones isométricas de tensión, fijada a una construcción especial. Se ha utilizado el software "Isometrics" (ver. 3.1.1), y la frecuencia de selección de datos se ha realizado en nivel de $500 \mathrm{~Hz}$. La muestra abarcó 269 personas examinadas del sexo masculino de 14.0 a 69,9 años de edad. Los resultados de la estadística descriptiva demostraron que en relación con la muestra examinada, los valores de la fuerza máxima demostrada (Fmax) para el brazo no dominante están en el rango de 462.8 до $529.0 \mathrm{~N}$, para la fuerza explosiva (RFDmax) en el rango de 1621.6 до 1972.8 N/s y para el impulso de la fuerza muscular (ImpF50\%max) de 8203.9 a 15552.3 Ns, mientras que los valores Fmax para el brazo dominante en el rango de 478.1 a $566.2 \mathrm{~N}$, para RFDmax en el rango de 1742.6 a $2119.0 \mathrm{~N} / \mathrm{s}$ y para ImpF50\%max de 9516.7 a 16845.1 Ns. Se estableció que se pueden medir fiablemente todas las tres características contráctiles examinadas de la mano, con lo que ICC está en el rango de 0.938 a 0.977 para Fmax, de 0.903 a 0.971 para RFDmax, y de 0.747 a 0.943 para ImpF50\%max. Como un valor representativo para las variables Fmax y RFDmax, sin tener en cuenta la dominación de un brazo o grupo de edad, debe tomarse la segunda prueba como mejor resultado, mientras que para la variable ImpF50\%max, en los grupos de edad de 35.0 a 49.9 y de 50.0 a 69.9, debe tomarse en general la primera prueba para ambos brazos, en el grupo de 14.0 a 19.9 años la segunda prueba y en la edad de 20.0 a 34.9 años el mejor resultado del brazo no dominante es la primera y del brazo dominante la segunda prueba.
\end{abstract}

Palabras claves: PRESIÓN DE MANO / FUERZA MÁXIMA / FUERZA EXPLOSIVA / RESISTENCIA DE CRITERIO / IMPULSO DE POTENCIA

Примљен: 26. 09. 2017.

Прихваћен: 11. 12.2017 